\title{
Botany
}

\section{African elements in Saramaccan Maroon plant names in Suriname}

\begin{tabular}{|r|l|}
\hline Journal: & Botany \\
\hline Manuscript ID & cjb-2021-0066.R1 \\
\hline Manuscript Type: & Article \\
\hline Date Submitted by the & 07-Jun-2021 \\
\hline $\begin{aligned} \text { Complete List of Authors: } \\
\text { Kan't Klooster, Charlotte; Leiden University Medical Center, Department } \\
\text { of Public Health and Primary Care } \\
\text { Haabo, Vinije; Saamaka project } \\
\text { van den Berg, Margot; Utrecht University Faculty of Humanities, } \\
\text { Department of Languages, Literature and Communication } \\
\text { Stoffelen, Piet; Botanic Garden Meise } \\
\text { Van Andel, Tinde; Wageningen University \& Research, Biosystematics } \\
\text { group; Naturalis Biodiversity Center }\end{aligned}$ \\
\hline $\begin{array}{r}\text { Is the invited manuscript for } \\
\text { consideration in a Special } \\
\text { Issue? : }\end{array}$ & $\begin{array}{l}\text { Vernacular names, Creole languages, Transatlantic slave trade, DRC, } \\
\text { Africa, Ethnobotany }\end{array}$ \\
\hline &
\end{tabular}

\section{SCHOLARONE Manuscripts}




\section{Title page}

Title: African elements in Saramaccan Maroon plant names in Suriname

\section{Authors list with institutional addresses:}

1. Charlotte I.E.A. van 't Klooster. Department of Public Health and Primary Care, Leiden University Medical Center, PO Box 9600, 2300 RC Leiden, The Netherlands. OCID: 0000-0001-9933-3523. Email: c.i.e.a.vantklooster@gmail.com

2.Vinije Haabo. Saramaka Project. Kennedyweg 92, 6708HB Wageningen, The Netherlands. Email: vinije.haabo@gmail.com

3.Margot Van den Berg. Humanities. Department of Languages, Literature and Communication. Utrecht University. Transcomplex, Trans 10, Room 2.11, 3512 JK Utrecht, The Netherlands. OCID:0000-00027239-4374 Email: m.c.vandenberg1@uu.nl

4. Piet Stoffelen. Meise Botanical Garden, Nieuwelaan 38, 1860 Meise, Belgium. OCID: 0000-0003-2547-0415 Email: piet.stoffelen@plantentuinmeise.be

5. Tinde R. Van Andel. Biosystematics group, Wageningen University, Droevendaalsesteeg 1, 6708 PB, Wageningen, The Netherlands. Naturalis Biodiversity Center. PO box 9517, 2300 RA Leiden. The Netherlands. ORCID: 0000-0002-4951-1894. Email: tinde.vanandel@naturalis.nl

\section{Corresponding author:}

Charlotte van ’t Klooster, c.i.e.a.vantklooster@gmail.com, 00918754140210 (India) 


\begin{abstract}
The ancestors of the Saramaccan Maroons, who were brought as enslaved Africans to Suriname, used their ethnobotanical knowledge and native languages to name the flora in their new environment. Little is known about the influence of African languages on Saramaccan plant naming. We hypothesized that Saramaccan plant names were more influenced by Central African languages than found so far based on ethnobotanical research, because data of the Central African region was scarce. We compiled a new database on Saramaccan plant names and compared these names with an unpublished plant name database from the Democratic Republic of the Congo and the earlier published NATRAPLAND database on Afro-Surinamese plant names to find comparable plant names for botanically related species in Africa. We further analyzed form, meaning, function and categories of Saramaccan plant name components by means of dictionaries and grammars. In total, $39 \%$ of the Saramaccan plant names had an African origin, of which $44 \%$ were African retentions, $54 \%$ were innovations and $2 \%$ were misidentifications with botanical links to Africa via other plant species. Most retentions were of Central African origin (62\%). The Bantu language that contributed most to Saramaccan plant names was Kikongo, followed by West African Kwa languages. Plant names reveal important information on the African origin of the Saramaccans, and deserve more scientific attention.
\end{abstract}

\title{
Keywords
}

Vernacular names, Local names, Creole languages, Transatlantic slave trade, DRC, Africa, Traditional knowledge, Ethnobotany. 


\section{INTRODUCTION}

Plants play a vital role in traditional societies. Studying plant names, their structure and meaning is useful for documentation and plant classification purposes but also for gaining a deeper understanding of the etymology of plant names (Berlin 1973, 1992) and the source domains or categories they belong to, such as animals, people, morphology or habitat (Leyew 2011; Turpin 2013). Plant names can also provide information on where people historically came from and with whom they had contact or exchanged knowledge with (Van Andel et al. 2014; Alcantara Rodríguez 2016). Gaining a better understanding of their origin and meaning can contribute to the survival of local systems of biological knowledge, particularly in societies that undergo rapid cultural changes (Martin 2004). In this study, we focus on the origin, use and social meanings of plants and their names among the Saramaccan Maroons in Suriname.

Between 1658 and 1825, the Dutch were responsible for disembarking at least 295.000 Africans to their plantation colony Suriname (Eltis and Richardson 2010), who originally came from Senegambia, the Windward Coast (Sierra Leone, Liberia and Ivory Coast), the Gold Coast (Ghana), the Slave Coast (eastern Ghana to Benin), the Bight of Biafra (Nigeria and Cameroon) Loango and Luanda (southern Gabon to northern Angola, now known as West Central Africa). Some enslaved Africans were captured several hundred miles inland, while others came from places much closer to the coast where the Dutch had their fortified strongholds (Eltis and Richardson 2010). As people were taken from different coastal and interior areas, they belonged to numerous African ethnic and linguistic groups (Mintz and Price 1992).

At the plantations where they were set to work, new contact languages emerged as interethnic means of communication. They were relatively rudimentary and unstable in 
structure, and had a limited vocabulary in the beginning of the contact setting. These languages formed a mixture of African and European languages, showing retentions as well as innovations, out of which the Afro-Surinamese Creole languages were born over the course of time (Smith 1987; Van den Berg 2007). The enslaved people who escaped from the plantations settled themselves in the tropical rainforest and are nowadays known as Maroons (Figure 1).

Figure 1: Left: Saramaccan Maroon village Pikin See. Yeeye Haabo†, Pikin Slee. Photographs made by C. van 't Klooster (2009). Right: Map of Suriname and the Maroon communities living in the interior. Drawing by Hendrik Rypkema, Naturalis Biodiversity Center.

The six Maroon communities in Suriname (Saramaccan, Matawai, Ndyuka /Aucan, Aluku / Boni, Kwinti and Paramaccan) all have their own distinct cultures and languages (Price 1973; Thoden Van Velzen and van Wetering 1988). With approximately 83,000 people, the Saramaccans are the largest Maroon community in Suriname and French Guiana (Price 2013). Together with Sranantongo, spoken by the descendants of enslaved Africans who remained in the coastal areas after the abolition of slavery in 1863, the Maroon languages are regarded as English-based Creole languages. Since Suriname was first colonized by the English in 1651, after which the Dutch took over in 1667, English had a major influence on the early development of the Surinam Creole languages (Smith 1987). After Sephardic Jews arrived from northeast Brazil, Essequibo (Guyana) and Europe (Livorno, Amsterdam), these languages were also influenced by the Portuguese (Arends 1999), particularly the Saramaccan and Matawai languages, as their forefathers escaped from plantations owned by Portuguese Jews (Price 1983; Smith 1987). During and after their self-liberation, the Saramaccans have also been in contact with indigenous communities and incorporated words 
from mainly Carib and Arawak origin in their language (Price 2010; Borges 2015). As a result, Saramaccan plant names are often a combination of African, European and Indigenous words which reflect a creolization process that merged ethnobotanical skills from various geographical and cultural sources into a new Afro-Surinamese knowledge system (Mintz and Price 1992; Van Andel et al. 2014).

The African origins of the Surinamese Creole languages have been a topic of linguistic study since the end of the $19^{\text {th }}$ century. Of all Surinamese Creole languages, Saramaccan has the highest percentage (5\%) of African words in the basic vocabulary (Smith 1987, 1999). But if one turns to culture-specific words that are used in domains such as religion, food and health care, the percentage of words that can be traced back to Africa is probably higher, as discussed by Huttar (1985) for Ndyuka, by Bilby (2000) for Aluku, and Price (1975a) for Saramaccan.

Huttar (1985) found 98 Ndyuka words of African origin including 16 plant species. Kwa and Bantu languages predominated, but various West Atlantic, Mande and Gur languages also acted as source. Smith (2015ab) who elaborated further on the works of Huttar (for Ndyuka) and Daelemans (1972) for Saramaccan, showed that the lexicons of the AfroSurinamese languages were strongly influenced by Central African Kikongo (Bantu language group) and West African Gbe languages such as Fon and Ewe (Kwa language group), and to a lesser extend Akan languages. In total 185 words of Kikongo and 138 words of Gbe origin were found in the Afro-Surinamese languages which included 18 Saramaccan plant names based on Kikongo and six on Gbe (Smith 2015cd). However, the Saramaccan plant names mentioned in the publications by linguists lacked botanical vouchers, which makes it difficult to link them to scientific plant names.

Van Andel et al. (2014), who traced the origin of Afro-Surinamese plant names linked to herbarium specimens, confirmed the significant role of Africans as agents in the spread of 
plant-related knowledge in Suriname and calculated that $43 \%$ of the 673 plant names with an African origin could be linked to languages from Gabon, Congo and Angola, which confirms that Central African languages had a major influence on Surinamese Creole languages. However, the linguistic and geographical origin of 167 Afro-Surinamese plant names (of which 84 Saramaccan) compiled by Van Andel et al. (2014) still remained unsolved.

Recently, a database was made available with Central African vernacular plant names by the Meise Botanic Garden (MBG) (Belgium), with more than 55.000 vernacular plant name records in several dozen local languages, with corresponding botanical vouchers collected during the colonial period in the area nowadays known as the Democratic Republic of the Congo (DRC). Since literature on vernacular plant names of the DRC is scarce, this database offered a new opportunity to trace previously unknown botanical links between Saramaccan and Central African plant names.

Saramaccan plant species, their uses and names reflect adaptive ethnobotanical knowledge systems that display both retention of traditional African knowledge and innovation. Our general aim is to fill the knowledge gap on the geographic origin of Saramaccan plant names and the traditional knowledge stored within these names. We have three research questions: (1) What proportion of Saramaccan plant names have an African origin? (2) What is the contribution of Central African languages to Saramaccan plant names? (3) Which manifestations of African heritage (e.g. references to animals, illnesses, plant characteristics, places) are found in Saramaccan plant naming?

As 14647 enslaved Africans from Central Africa were brought to Suriname from 1665 till 1719 (Smith 2015a), we hypothesize that several of the Saramaccan plant names with unknown origins are linked to botanical species in the DRC. Furthermore, we expect that the Saramaccans, with their oral culture, store all sorts of information in their vernacular plant names to help members of their society remember their traditional plant-related knowledge. 
The outcomes of this study will contribute to the preservation of Saramaccan heritage by revealing the cultural, historical and environmental knowledge hidden in their plant names and the African contribution to the formation of their language, and add to the discussions on the cultural agency of enslaved Africans in the New World.

\section{Methods}

\section{Data collection}

Data on 678 Saramaccan plant names were extracted from the NATRAPLAND database published by Van Andel et al. (2014), based on Van 't Klooster et al. (2003). We also included Sranantongo plant names from NATRAPLAND used by Saramaccans, unpublished names of rice varieties documented by Sally Price from the 1960s onwards, some names of rice varieties from Baumgart et al. (1998), and Saramaccan plant names from ethnobotanical studies conducted among Saramaccans in Suriname (Van 't Klooster et al. 2016, 2018, 2019; Ruysschaert 2018) and French Guiana (Sauvain et al. 1988). After merging records with identical plant names for botanically related species, this resulted in a final database with 978 Saramaccan plant names.

\section{Data analysis}

For each Saramaccan plant name record, we provided the corresponding scientific name and family, the great majority based on voucher specimens present in the herbarium of Naturalis Biodiversity Center (L), which is located in Leiden, the Netherlands. All vernacular names were checked for their latest spelling following the regulations of Saramaccan native, ethnolinguist and second author V. Haabo, who is working on a new Saramaccan-Dutch dictonary and collaborated on a new orthography for Saramaccan (Price and Price 2015). A column with the original Saramaccan name as found in literature or specimen labels was kept 
for reference purposes. Since Saramaccan classification provides valuable insights as to how they conceptualize their environment, the complete plant names were kept in our database, whether they consisted of simplex words, compounds or phrases. To investigate the cultural meaning embedded in the plant names, we analysed the name components in terms of form and meaning and traced them back to their source languages, whether African, European or Indigenous. We also consulted the online dictionaries on Languages of Suriname of the Summer Institute of Linguistics (SIL 2003), based on the work of linguists Naomi Glock and Catherine Roundtree in the 1970s.

Saramaccan plant names were compared with names in Indigenous and European languages in published literature, etymological libraries and databases (Fanshawe 1949; Smith 1987; Van 't Klooster et al. 2003; Smith and Cardoso 2004; Courtz 2008; Van der Sijs 2010; Van Donselaar 2013; Van Andel et al. 2014; Harper 2020). For the African plant names, we used the JSTOR Global Plants database (2020), the compendium on useful plants of West Tropical Africa (Burkill, 1985-2010), encyclopedias on local and scientific plant names (e.g. Quattrocchi 2002, 2012), the MBG database on plant species collected in the DRC, previous work on this database by Fundiko et al. (2015), and ethnobotanical literature for the DRC (e.g., Latham and Konda ku Mbuta 2017) and Angola (Lautenschläger 2018). We furthermore analysed dictionaries on relevant Central and West African languages, such as Kikongo (Bentley 1895) and Fon (Segurola and Rassinoux 2000), and linguistic and historical studies for these areas (Vansina 1960, 1978; Mobley 2015; Smith 2015cd) to provide possible meaning and supporting evidence to the origin of the plant names.

We marked those Saramaccan plant names that showed morphosyntactic, phonological or semantic similarities with African vernacular plant names for botanically related taxa. Additional information was added regarding the country of origin and language of the African vernacular plant name and references (vouchers labels, literature). We solely added 
translations of plant name components found in (African) dictionaries when their form and meaning showed resemblance with a plant use or characteristic. All current scientific plant names were checked with the Plants of the World Online database (2021).

Surinamese plant species carrying a plant name of African origin provided evidence of the association with either botanically related African plant species or African plants with similar morphological features or uses. When it was unclear how the lexical item entered into the Saramaccan language or when linguistic information provided extra information on the meaning of a plant name, we listed both the botanical and the morphological or semantic proof.

We checked the existing botanical links between Saramaccan and African plant names again and added etymological meaning to our database, a more likely geographic origin or better botanical or linguistic proof. Percentages were calculated for the geographical and language origin of the Saramaccan plant names for which we found botanical proof in Africa.

We further analyzed general trends in Saramaccan plant naming (e.g., reference to animals, plant morphology) for the African-based vernaculars to analyse how Saramaccan plant names were formed over time, following general theories on folk taxonomy (Berlin 1973, 1992; Martin 2004). We used the term 'mixed origin' or 'hybrid compound' for plant names with a combined African-European, African-Indigenous, European-Indigenous, Indigenous-Asian or African-European-Indigenous origin. To verify which languages and geographical regions in Africa had the largest influence on the formation of Saramaccan plant names, we used historical sources on the origin of the enslaved Africans in Suriname (Eltis and Richardson 2010) and compared these with the region of origin of the African plant names and lexical items embedded in Saramaccan plant names, as done by Alcantara Rodríguez (2016) for Papiamento plant species on Curaçao. 
The African continent is believed to host one third of the languages spoken worldwide (Vossen and Dimmendaal 2020). These languages are generally classified into four language phyla known as Niger-Congo, Afro-Asiatic, Nilo-Saharan, and Khoisan, which can be subdivided further into respective families and subgroups which were used to trace the African languages that influenced Saramaccan plant names. To avoid multiple references made by the same or different authors for the same African language, and to use the modern spelling of these languages, we used the Ethnologue database (Eberhard et al. 2020). We followed the language group classifications of the Glottolog database (Hammarström et al. 2020). We did not intent to conduct a thorough linguistic semantic study on plant names, nor do we pretend to be complete in our list of Saramaccan plant names, so our study has an explorative nature.

\section{Results}

\section{Origin of Saramaccan plant names}

Our final database contains all 978 Saramaccan plant names known so far in literature, and their possible African, European, Asian or Indigenous elements. A list with information on each Saramaccan plant name (e.g. scientific name and family, relevance Suriname, it's botanical relative in Africa, local African name and relevance in Africa) is available as supplementary table to this article (Supplementary table S1).

Out of the 978 vernacular plant names, $639(65 \%)$ contained European elements, 382 (39\%) had African elements, 190 (19\%) had Indigenous elements and $4(<1 \%)$ had elements of Asian origin. For the remaining 49 Saramaccan plant names (5\%), the source of origin remained unknown. Further analysis revealed that $646(66 \%)$ of the plant names contained elements of one single origin, while for 283 (29\%) contained elements of 'mixed' origin, a combination of African, European, Asian and/or Indigenous elements, so the total percentage 
of recorded elements is higher than $100 \%$. The 283 hybrid plant names consisted mostly of African and European languages $(n=180,64 \%)$, although 23 combinations of African and Indigenous languages were present (8\%). In some rare cases, such as 'bandya-wata aluwau' (Protium heptaphyllum (Aubl.) Marchand), a fusion of African, European and Indigenous elements was found. Here, 'bandya' meaning riverside, is derived from 'm-baansya' (Kikongo) meaning side (Smith 2015c), while 'wáta' (water) is derived from English or Dutch (Smith 1987). The lexical item 'aluwau' is borrowed from the Carib word 'arouaou' which is used for the same plant species (DeFilipps et al. 2004). The tree P. heptaphyllum grows on higher river banks, explaining the name 'riverside aluwau' (Van Roosmalen 1985; Fern 2020). In 78 (28\%) of the cases, the hybrid compound names were based on European and Indigenous elements. One name was based on Asian and Indigenous elements. These hybrid compound names reflect the process of creolization and the innovative way of creating new plant names, while at the same time maintaining links with the motherland Africa.

The 382 Saramaccan plant names for which we found a possible African origin were divided into two main categories: names created by retention (based on botanically related species) and names created by innovation (referring otherwise to Africa) of which examples are presented in Table 1. While 168 vernacular plant names (44\%) were based on African retentions, 206 Saramaccan plant names were based on innovation (54\%), and eight (2\%) were so called 'misidentifications', plant names given to species that resemble other species with a botanical link to Africa. For example, the ferns Lindsaea sp. and Adiantum fuliginosum Fée are known as ‘biibiiuwii’ by the Saramaccan. They were 'misidentified' for Triplophyllum funestum (Kunze) Holttum (also known as 'biibiiuwii') in Suriname, which can be linked to the name 'bilelele' (Tembo) in the DRC for Triplophyllum pentagonum (Bonap.) Holttum. For 81 retentions, we found additional linguistic proof for lexemes in African dictionaries and literature, further strengthening their African origin. The 
retentions suggest that the Saramaccan ancestors associated the plants in their new surroundings in Suriname with the flora of their African homeland and used partly or completely the same or similar African plant vernaculars to name them. The plant species for which we found botanical proof in Africa belonged to 49 different plant families, mostly Fabaceae followed by Poaceae, Moraceae, Piperaceae and Malvaceae.

Table 1: Examples of Saramaccan plant names that strongly resemble African names for botanically related taxa (retentions).

\section{Geographical and linguistic origin of African-derived plant names}

The Saramaccan plant names we linked to botanically related species in Africa (retentions) provide us with information on where the enslaved Africans came from. Out of 168 Saramaccan plant names with an (partial) African origin, 104 (62\%) suggest a Central African origin (Gabon, Congo, the DRC and Angola), while 22 (13\%) came from Benin, 19 (11\%) from Ghana, 20 (12\%) from Ivory Coast, Liberia and/or Sierra Leone, $10(6 \%)$ from Nigeria, 5 (3\%) from Senegal, 1 (1\%) from Togo and 1 (1\%) from Guinea. As some names were combinations of words from several African languages, the total percentage is larger than $100 \%$.

Out of the 168 retentions, $154(92 \%)$ were based on languages belonging to the NigerCongo phylum. Only three (2\%) were part of the Afro-Asiatic phylum and 1 (less than $1 \%$ ) belonged to the Nilo-Saharan phylum, while for the remaining 11 names $(6 \%)$ we were unable to trace the language origin due to a lack of information, such as an unclassified language in the MBG database. Within the Niger-Congo phylum (Fig. 2A), most of the Saramaccan plant name retentions belonged to the Atlantic language subfamily, which is a largest language group within that phylum, spoken by people in the coastal areas of Western 
Africa. The remaining languages belonged to Mande (e.g., Bambara, Mende and Mandinka). In some cases, two possible retentions were found (belonging to different language families).

Figure 2. A-F. Language families and subfamilies belonging to the Niger Congo phylum contributing to Saramaccan retentions in percentages $(\%)$.

A closer look at the Atlantic language group (Niger Congo phylum) shows that de Volta Congo sub-language group (Fig. 2B) scored the highest, of which the Benue-Congo languages (incl. Bantu) (Fig. 2C) were best represented, followed by Kwa languages (incl. Gbe languages Fon and Ewe), and some languages belonging to the North Volta Congo such as Daagare, a Gur language spoken in Ghana. Within the Benue-Congo languages (Fig. 2D), the majority of the retentions were Bantoid which can be divided into North and Southern Bantoid languages. Only one vernacular (1\%) belonged to the Northern Bantoid group of languages while the rest were Southern Bantoid languages (99\%) to which the (Narrow) Bantu languages belong that are spoken in sub-Saharan Africa (no figure). We found that most retentions within the Narrow Bantu group belonged to the Central Western Bantu languages (Fig. 2E) and were mainly Kikongoic (Fig. 2F) to which Kikongo belongs, which is spoken from north-western Angola to western DRC, southern Gabon and western part of the Republic of the Congo.

From the 168 scored retentions, 81 (48\%) were Bantu and 47 (28\%) were Kikongoic. Kikongo $(n=37,22 \%)$ was the most prominent African language of all the Saramaccan retentions, although other languages were also recorded for this region such as Tembo, Lombo, Lingala, Luba-Katanga, Luba-Kasai and Zande. The 60 botanical links with Saramaccan plant names found in the MBG database, represented 21 languages (e.g. Villi, 
Zande, Luba-Kasai) out of the more than 200 languages that are nowadays spoken in the DRC (Muturzikiña 2011; Makomo 2012).

\section{African heritage in Saramaccan plant names}

\section{Reference to animals}

Saramaccan plant names refer to animals to express an ecological relationship between the plant and animal or when there is a morphological association (plant looks like a part of the animal) (Supplementary table S1). Morphological associations with 14 animal species were made. Porcupines appeared most regularly: in 'makayasubi' (Chrysobalanus icaco L.), 'makaya' seems to be derived from the Hausa word 'makaya' for porcupine (Robinson 1914), while 'subi' (to climb) stems from the Portuguese word 'subir' (Smith and Cardoso 2004), referring to the spiny animal that climbs the small tree to eat its fruits (Plants for a future, 2020). Although the Hausa word 'makaya' has lost its meaning in Saramaccan as a separate word for a spiny creature, the name 'maka mbeti' (spiny animal), is still in use for the Brazilian porcupine (Coendou prehensilis) (SIL 2003). 'Maka' was also used for other spiny or rough things like fishbones or the course 'Osnabrugs linen' fabric (Blom 1786). Nowadays, the lexeme 'maka' is used in all Afro-Surinamese languages as a suffix for plants with thorns or spines. For example, spiny lianas of the genus Smilax are known as 'agbagomaka', in which 'agbákò', means accident or misfortune in Yoruba (Church Missionary Society 1913). Since Smilax thorns can be harmful, the Saramaccan name warns about the misfortune these lianas can bring. Other Saramaccan vernacular plant names for spiny lianas are 'aka(1)amaka (tatai)' for Mimosa myriadenia (Benth.) Benth. and Senegalia tenuifolia (L.) Britton \& Rose, for which we found botanical links in Nigeria where spiny Vachellia gerrardii (Benth.) P.J.H. Hurter and V. hockii (De Wild.) Seigler \& Ebinger are refered to as 'bakarkayaa', and the spiny Parkinsonia aculeata L. is known as 'bagaauuwar makka' in Hausa (Blench 2007). We also found that the Saramaccan vernacular 'akaya', the 
Papiamento 'kaya kaya' (in Curacao) and the Fon vernacular 'àkàyá' and 'àkàyá asu' (Benin) are all used to name thorny Cleome species (De Souza 2008; Alcantara Rodríguez 2016). The Fon name stems from the Hausa word 'makaya' or 'kaya' meaning thorn (Robinson, 1914) as they have no meaning in Fon. The Matawai Maroon village 'Makaya Pingo', meaning spiny bush hog (Tayassu pecari, (Link, 1795)) (ACT 2015), further supports our finding that the African lexeme 'mayaka' found its way to Suriname.

Other African animals that feature in Saramaccan plant names are the antelope, 'mboloko' (Lingala) (Divuilu 2005) used for Piper guineense in the DRC and for Piper sp. in the Saramaccan vernacular 'bookokindi' (antilope's knee), referring to the thick nodes on the stem. The Saramaccan name 'pongo' has no meaning in Saramaccan, but is given to Cayaponia lianas of which the fruits are eaten by monkeys (Van Roosmalen 1985). 'Pongo' is a Kikongoic word for monkey spoken in the Mayombe hills and derived from 'mpungu' (Vili) or 'yimpungu' (Kikongo) (OED 2020). The Twi word 'nkra(n)', referring to ants (Evangelische Missionsgesellschaft 1909) appears in the Saramaccan plant name 'kantasi' (Adiantum latifolium Lam) and 'kantamasi' (Palicourea violacea (Aubl.) A.Rich.). Both names relate to 'akantasi', a malevolent spirit that lives in termite nests (Van Andel and Ruysschaert 2011). The lexeme 'tasi' comes from the English thatch (Smith 1987), meaning to pile up leaves. In Saramaccan, the word 'akantasi' refers to a termite hill. The Ghanaian capital Accra is named after the ant-hills seen around the city (Akuamoa 2011). Other African animals that figure in Saramaccan plant names were described earlier by Huttar (1985) and Van Andel et al. (2014) for Ndyuka plant names, like the monitor lizard (Varanus sp.) known as 'mbaambi' in Masangu which lent its name to Sabicea oblongifolia (Miq.) Steyerm., called 'bambitongo' (lizard's tongue), or 'nzau' (Ndyuka) which is derived from 'nzawu' (Kikongo) for elephant, a lexeme lent to various species in Suriname. 


\section{References to people and places}

Vernacular plant names may also refer to African locations and ethnic groups.

Mansoa alliacea (Lam.) A.H.Gentry is known as 'agbonengetatai', meaning 'liana of the Agbo people'. The Saramaccan term 'Agbo' is also used for one of their clans and probably derived from 'àgbǒ' (Fon) referring to Abomey, the capital of the former Kingdom of Dahomey (Benin), in the past referred to as Agbóme (Smith 2015d). A Saramaccan rice variety documented by Sally Price in 1967 as 'akwiibi', meaning small person, refers to the Kwinti Maroons. The Saramaccan used to call Kwinti 'dee Akwiibinenge' (the small people), as among them were many small people. Akwiibi might stem from 'Ekwubi', a common family name in Yoruba used in Nigeria.

The Portuguese introduced bananas and plantains (Musa spp., native to Asia) from Africa to Brazil where they became known as 'banana' (term from Guinea) and 'bacoba' (from Angola) in the seventeenth century (Alcantara Rodriquez and Van Andel 2019; Van Donselaar 1989). The Bakuba may be the source for the vernacular name 'bacoba' (Portuguese) and 'bakuba' (Saramaccan) for sweet bananas that came into use in Northern Brazil and Suriname. Before 1525, the Portuguese came in contact with the Bushoong (an ethnic group that became the Bakuba after their migrations) in Mayombe (a transnational region in the (south)west coast of Gabon, west of Congo-Brazzaville, west of DRC and Angola (Cabinda)), or on the banks of the River Congo (Vansina 1960). Trade in New World crops (e.g., maize, cassava) took place with the Bakuba via the Kongo Kingdom, which resulted in the Bakuba shifting to maize instead of cultivating bananas around their houses (Vansina 1978; Lowes et al. 2015). In the late $16^{\text {th }}$ century, European merchants (mostly Dutch and Portuguese) founded the city of Boma on the Congo River estuary, $100 \mathrm{~km}$ from the Atlantic Ocean, which acted as a slave market and trading center. Nowadays it is the second port of the DRC and forms an outlet for palm oil, bananas and timber from the forests 
of Mayombe to the north (Edelson 2014; Encyclopaedia Britannica 2021). In the late $18^{\text {th }}$ century, the majority of the enslaved Africans sold on the Loango Coast came from Mayombe and the Loango Kingdom north of the River Congo (Mobley 2015).

\section{Reference to human body parts}

Saramaccan folk taxonomy shows several examples of plant names of African origin referring to human body parts. The Saramaccan plant name 'ndulundulu' (Tanaecium bilabiatum (Sprague) L.G.Lohmann) stems from the Kikongo word 'ndulu' meaning liver (Fundiko et al. 2015). The pods of T. bilabiatum are shaped like a liver and the plant is highly toxic (Lima et al. 2016). In the DRC this vernacular is used for Picralima nitida (Stapf) T.Durand \& H.Durand (Fundiko et al. 2015), of which the seeds are toxic to the liver (Sunmonu et al. 2014). In West Africa P. nitida is used to treat jaundice and yellow fever, ailments that relate to liver problems (Erharuyi et al. 2014). The Saramaccan vernacular 'degibonbo' is used for the Dilleniaceae lianas Tetracera asperula Miq. and Davilla kunthii A.St.-Hil. The name stems partly from 'degi', meaning fat or to consolidate (from 'dik' in Dutch), and 'bombo' meaning vagina (Bruyn 2002). In the DRC 'bombo' (Lombo) is used for the botanically related species Tetracera rosiflora Gilg. The Saramaccan use these rough-leaved lianas in genital steam baths that make the vagina swollen and tight, which gives a burning, scraping feeling during sexual intercourse (Van Andel et al. 2008). In many African cultures this practice of 'dry sex' exists, but no botanically related species could be found in Africa with the same use.

\section{Reference to habitat}

Plant names can also refer to the the locality where the plant grows, like Pontederia crassipes Mart. a waterplant known as 'tookoogbagba' in Saramaccan, and as 
'togble', 'togwede' or 'gbà' in Fon in Benin (Akoègninou et al. 2006). In Fon 'togotogoò' means in a circle and 'gbà' (Fon) means swamp (Segurola and Rassinoux 2000). The Saramaccan forefathers probably named the plant after its circular leaves and its swampy habitat. The Saramaccan vernacular 'azokopampa' is associated with Sphagneticola trilobata (L.) Prusky, a common species in open vegetation that spreads easily and is regarded as an invasive species in many countries (CABI 2020). In Kikongo, the term 'azoko' means 'in many places', while 'pampa' (no meaning in Saramaccan), means 'to act carelessly, thoughtlessly’ (Bentley 1895).

\section{Morphological and organoleptic characteristics}

Plant names also refer to life forms, the shape of specific plant parts, thorns, taste, color, exudate, or poisonous compounds. The Saramaccan vernacular 'kobo' is given to Caryocar microcarpum Ducke, a fish poison plant, of which the leaves are crushed and thrown into the water to catch fish that come to the surface to breathe. The Saramaccan vernacular '(ma)kobo' (fish) could stem from '(ma)kuba' (Kikongo), meaning thornfish (Smith 2015c) or from 'koboma' (Lingala) meaning to kill (Fundiko et al. 2015). In the DRC, the vernacular 'kobo' (Mangbetu) is used for Spondianthus preussii Engl., which is known as fish poison as well (Neuwinger 2004). For the Saramaccan plant name 'kisangula' (Maprounea guianensis Aubl.) we found that the same vernacular in Kikongo is used in the DRC for its botanical relative M. africana (Arkinstall 1979). The lexeme 'ngola' in Lingala means red (Divuilu 2005), and both species have red fruits. The vernacular '(be) sangaavu' (Costus spp.): is a retention of 'nsangalavwa/nsangalavu' (Kikongo) for Costus in the DRC and Angola, where the prefix 'be' is used to indicate a red-flowered Costus.

\section{Reference to illnesses}


The Saramaccans use many medicinal plants in their health care practices (Van 't Klooster et al. 2016), and plant names often reflect their medical uses. In the plant name 'kulakatanga' (Piper spp.), 'kula' means healing or recovery in Saramaccan, which stems from 'kula' (Kikongo, DRC), meaning to cast or to drive off, while 'katanga' comes from 'nkátánga' meaning cramp in both Kikongo and Saramaccan (Smith 2015c). The linguistic evidence provided by Smith (2015c) for the African origin of 'kulakatanga' is supported by ethnobotanical data, as Saramaccans use many Piper species to sooth body pain and stomachaches (Van Andel and Ruysschaert 2011). The species Phyllanthus amarus Schumach. \& Thonn. ('aheni') is used by Saramaccans to break down kidney stones (Van Andel and Ruysschaert 2011), a practice also found in Africa for the same species (Eweka and Enogieru 2011). In Benin, the species is known as 'ahin bishowo' in Yoruba (De Souza 2008) of which the Saramaccan 'aheni' is derived. In Yoruba, 'pahin keke' means to gnash while 'keke' means to be small (Church Missionary Society 1913). The Saramaccan name seems to stem from the Yoruba terms referring to the crushing of kidney stones.

A number of Saramaccan plant names refer to 'fiofio', which means curse and refers to a magical disease related to a bug. Herskovits and Herkovits (1934) report that 'fio-fio' is a brown bug or a spirit that brings sickness or death and claim 'fiofio' is a Bantu word for a medicinal herb used by the peoples of Loango (Central Africa), but unfortunately do not mention any scientific name. Our literature search revealed that the herb Psorospermum febrifugum Spach is known as 'mfiofio' in Kikongo and used against epilepsy, skin parasites, insect bites and sand fleas in different parts of Africa (Burkill 1985-2010; Bum et al. 2005). In Suriname, the juice of 'bobifiofio' (Struchium sparganophorum (L.) Kuntze) is used against epilepsy, and to treat the magical children disease 'fiofio' caused by arguing family members (Van Andel and Ruysschaert 2011). This corresponds to a remark by Herskovits and Herkovits (1934) that 'fio-fio' could be an old Dahomean term meaning anger. In 
Suriname, several Palicourea species are used in rituals to calm down the angry Apunku spirit (Bantu origin). They are also associated with the malicious Akantasi spirit that lives in termite hills. When a provision ground is made near a termite hill, this can upset the Akantasi, who will take revenge on the family of the farmer. Akantasi's anger is expressed by little foam bubbles on the termite nest, which are caused by spittle bugs that live on tree roots growing in the fertile soil of the nest. The word 'bobi' is derived from the English 'bubby', now booby for a woman's breast (OED 2020). The herb Euphorbia hirta L., known as 'fiofio-uwii' by Saramaccans, is used in herbal baths to reduce the effect of 'fiofio', while Nicotiana tabacum L. ('boifiofio') is sprinkled around the village to chase away angry spirits that causse illnesses (Van Andel and Ruysschaert 2011). Tobacco leaves are widely used in Suriname to suffocate botfly larvae in the skin, and the Saramaccan word 'boi' refers to a boil or abcess.

\section{Reference to supernatural beings}

Spirits play an important role in Saramaccan daily life and many plant species are associated with them. Protium stevensonii (Standl.), '(matu)mboomba' in Saramaccan, is a large tree that grows in lowland rainforest (Fern 2020). While 'matu' means forest, derived from the Portuguese 'mato' (Smith and Cardoso 2004), 'bo(e)mba' refers to a goodhearted Maroon water god who dwells in rapids (Benjamins and Snelleman 1917). The name of this god seems to be derived from 'mbombo' or 'bumba', the creator god of the Bakuba people in the DRC. In their creation myth, 'mbombo' was a white giant who ruled over the earth in the beginning of time (Knappert 1979). Another source for the Surinamese water god 'boemba' could be 'mbumba', a central mythic figure in Yombe cosmology (Mobley 2015).

Species such as Hyptis recurvata Poit. and Dianthera pectoralis (Jacq.) J.F.Gmel. are known as 'tone uwii', meaning rivergod weed (Van Andel and Ruysschaert 2011). The 
Saramaccan use 'tone' also for mentally retarded people and albinos (Herskovits and Herskovits 1936; Price and Price 1991), a term based on Tonneïn Toema, a god who punishes those who pollute the water (Benjamins and Snelleman 1917), described by Knappert (1977) as an African god in Bakuba mythology. The preparation of a magic herbal mixture ('tone obia') to invoke the rapid gods to cause heavy rainfall and make rivers unnavigable helped the Saramaccan in the past to get rid of their enemies (Price and Price 1991).

West African gods also appear in Saramaccan plant names like 'vodu-uwii' and 'papauwii', both used for Dianthera pectoralis (Jacq.) J.F.Gmel. While the Saramaccan word 'vodu', also known in Haiti as ‘voodoo' (Smith 2001) stems from vodún (Fon) or vodú (Ewe), the name of a snake god in Benin and Ghana (Smith 2015d), 'papa' means god in Fon (Benin). In Suriname, both 'vodu' and 'papa' refer to the Boa constrictor snake that is used by this god as its vehicle. However, 'papa' can also refer to the 'Papá negroes' which came from the Popo region on the border of Togo and Benin (Van Andel et al. 2014). The species Dianthera cayennensis (Nees) Griseb., known by the Saramaccans as 'apunku dangdang', is botanically related to Justicia ladanoides Lam. known as 'dangdang'(Chamba) in Nigeria (Burkill 1985-2010). The name 'apunku dangdang' relates to the Saramaccan forest spirit A(m)punku, whose name is based on the god 'nzambi ampungu' among the Kikongo (Bentley 1895), in which 'm-púungu' (Kikongo) means powerful (Smith 2015d).

\section{Reference to sound}

Onomatopoeia have been recognized as a major lexical class in West-African languages (Dingemanse 2018). They refer to the process of creating a word that phonetically resembles the sound that it describes. We found 14 possible onomatopoeia among the 978 Saramaccan plant names. Several Crotalaria species and the palm Astrocaryum vulgare Mart. are known in Saramaccan as 'tyotyo', which means 'to pound', referring to the sound made when 
clothes are beaten on the rocks when washed by hand. In the Ivory Coast, the vernacular 'tio' (Mandinga) is used for peanuts (Burkill 1985-2010), while in the DRC 'itotjo' (unclassified language) it is used for Dioclea reflexa Hook.f. The seeds of both Fabaceae species are used in the manufacturing of soap or shampoo in Africa (Jide 2010; Geetha et al. 2013; Yaradua and Shah 2018). In Brazil, Astrocaryum seeds are used as an ingredient in shampoos, soaps and conditioners (Pinto 1963; Fern 2020). So far, we have no ethnobotanical evidence that Crotalaria spp. or Astrocaryum sciophilum (Miq.) Pulle ('muumuu' (Sa) from 'murumuru' (Ca)) are used for this purpose by the Saramaccans, although their vernacular names refer to such a use. Another example is the Saramaccan vernacular 'waaalutu' given to Coccoloba uvifera (L.) L., based on the English 'root' and the onomatopoeia 'waaa' for 'to separate or disperse'. C. uvifera has large spreading roots that fortify riverbanks as they hold back the soil.

\section{Other features in Saramaccan plant naming}

Some plant species carry a number of different African-based Saramaccan names. The large tree Balizia pedicellaris (DC.) Barneby \& J.W. Grimes is not only known as 'be azau' (red elephant), a Saramaccan innovation, but also as 'powkondyo'. In Saramaccan, 'konyo' means massive. Some Saramaccan plant names are fusions of two leximes meaning the same, but derived from different linguistic origins. For example, in 'apaku pesi' (Canavalia brasiliensis Mart. ex Benth), the lexeme 'apaku' stems from 'akpaku' (Fon) and 'pesi' from pea (English) both meaning 'bean' (Segurola and Rassinoux 2000; Smith 1987).

Saramaccan plant names often start with a word-initial 'a', like in 'abenbele' (translated as 'the red nbele'), a name given to a Pouteria species that stems from 'mbala' (Mba) given to Gambeya africana (A.DC.) Pierre in the DRC. 'Akandauwii', is derived from 'kanda' meaning candle, a candle weed (Smith 1987), and 'amiomio', the Saramaccan term for 
Ricinus communis L., is based on 'myonmyon', the Gun name (Benin) for the same species (De Souza 2008). In the Gbe languages, 'a- is a noun class prefix, indicating a word class (Aboh and Smith 2015), but in Saramaccan word-initial a- has lost this function and it is not considered a prefix.

Another feature of Saramaccan is the dropping of the Kikongo ' $n$-' prefix in plant names. 'Nkengezi', meaning razor-edged grass (Bentley 1895), became 'kengeesi' for the sharpleaved Scleria secans (L.) Urb. in Saramaccan. Kikongo words like 'nsafu' meaning foulness (malodorousness, stinkyness) became 'safu' in 'safukali' (Guarea spp.), and 'nkisi' meaning holy or sacred became 'kisi' in 'kisima' (Humiria balsamifera var. floribunda (Mart.) Cuatrec.) in Saramaccan.

\section{Discussion}

\section{African retentions}

Our data showed that $39 \%$ of the Saramaccan plant names had a (partial) African origin and that they reflect a complex of retentions and innovations. Our findings support the suggestions of Price (1975a) that the African contribution in Saramaccan could be up to 50\%. Food, health care and religion are highly culture-specific domains, so in contact settings this is where retention due to transfer is more likely to occur. Out of the 678 Saramaccan plant names recorded in the database from Van Andel et al. (2014) 84 remained unknown, for which we tried to find botanical related species in Central Africa. For 64 of these, we have found African elements in 28 names, 29 had European elements, 13 had indigenous elements, and two were Asian. Still, for 48 Saramaccan plant names we could not trace a source language. 
The Saramaccan plant names for which we found botanical links in Africa were mostly (62\%) from Central African origin, which is a much higher percentage than the $43 \%$ calculated by Van Andel et al. (2014) for all Afro-Surinamese languages together. The higher links to Central Africa can be explained by the newly added MBG database of Congolese plant names, which led to 60 previously unknown retentions of Saramaccan plant names. We also found 9 additional retentions in literature sources for this area (e.g., Lautenschläger et al. 2018). Our findings correspond with our expectation that (West) Central Africa, has substantially influenced the Saramaccan language. While most of the African-based Saramaccan plant names belonged to the Niger-Congo phylum, we also found some retentions of Hausa plant names (Afro-Asiatic phylum) due to the Hausa trade in enslaved Africans and kola nuts (particularly Cola nitida (Vent.) Schott \& Endl.) via their ancient caravan routes from the Sahel to the West African coast (Isichei 1997).

The strong influence of Bantu languages (mainly Kikongo) in the formation of Saramaccan plant names corresponds with the findings of Smith (2015a). Kikongo (Bantu) was the most prominent African language influencing Saramaccan retentions. This large contribution of Kikongo can be explained by the fact that this language was spoken in areas where the Dutch colonizers purchased their slaves from e.g. Malembo, Cabinda (Voyagers database, 2021).

Most languages for the Saramaccan retentions belonged to the Bantu group, followed by Kwa, which can be explained by the fact that from 1675 to 1719 most enslaved Africans in Suriname were Eastern Gbe and 'Kikongo speaking' people from the Slave Coast and Loango Kingdom. After 1720, when the Gold Coast (Ghana) became the main supplier of African captives, more Akan-speaking people were taken to Suriname (Eltis and Richardson 2010; Smith 2015a). The Saramaccan community, however, was formed between 1690 and 1710 (Price 1983), long before the arrival of the Akan-speaking people. As a result, the 
number of Akan-retentions in Saramaccan plant names was much lower, as were the number of Akan lexical items found by linguists (Smith 2015a). As mentioned by Huttar (1985), many languages outside Kwa and Bantu should be taken into consideration as possible sources for the Maroon languages in Suriname. Indeed, for some plant names we found a botanical relative in less expected language groups such Mande (e.g. Bambara, Mandinka or Mende) or Gur (Daagare or Ntcham), spoken in Ghana and Benin.

Within the Benue Congo language group, to which the Bantoid languages belong, Igboid and Yoruboid languages such as Yoruba were also present. An analysis of the online Voyages Database showed that before 1675, enslaved Africans in Suriname were not only captured from Central Africa but also from Nigeria, who spoke a great variety of languages including Ijo, Igbo and Igboid languages (Smith 2015b). Although it remains unclear, how these languages might have influenced the Afro-Surinamese languages, we found one possible retention based on an Igbo plant name. Fortes-Lima (2017) showed in their genetic analysis of Maroon individuals from Suriname and French Guiana that they shared most of their DNA with people from Benin and Nigeria which included 19 Saramaccan individuals. The Maroon admixture profiles closely matched that of present-day Fon, Bariba, Yoruba and Esan peoples. This could explain the Fon and Yoruba influence we found in Saramaccan plant names. However, their sample size ( $\mathrm{n}=107$ for all Maroons) was small and cannot be representative for all Maroons in Suriname and French Guiana.

A number of languages that are spoken in the interior of the DRC also contributed to the Saramaccan plant names, such as Zande, Tembo and Luba-Katanga and Luba-Kasai. This confirms the conclusion of Eltis and Richardsson (2010) that enslaved Africans were captured hundred of miles inland by traders and took months to reach the coastal areas where they were sold to the Europeans (Mobley 2015). The Europeans obtained their captives 
mainly via traders controlling the interior slave market and only documented the place where they bought their enslaved (Mobley 2015).

\section{African innovations}

For 206 Saramaccan plant names with a possible African origin we did not find any botanically related species in Africa, but found similar African words in dictionaries, historical and linguistic literature. This shows that enslaved Africans used words of their own lexicon to give new names to Surinamese plants they were not familiar with, based on their color, shape, growth form, habitat or uses. We found that 74 of these innovations were influenced by Bantu languages (of which 62 Kikongo), and 84 were influenced by Kwa languages (of which 59 Fon), while the rest related to other smaller language groups. These numbers can be biased as variations of one word can occur in different languages belonging the same language group: the Saramaccan word 'vodu' (snake god) can stem from 'vodún' (Fon) or 'vodú' (Ewe), both meaning god (Smith 2015d).

\section{European influences}

Although we focused on the African legacy, we acknowledge the dominance of European langueages in Saramaccan plant names, two thirds had European elements. Our results are slightly different to those of Van Andel et al. (2014), who found that only 53\% of the Saramaccan plant names could be linked to a European lexical item. The higher European influence in our data analysis (65\%) was partly based on our inclusion of prefixes (black, white, big, small), as they contain important information for Saramaccan plant classification and identification. Removing prefixes from our analysis led to a decrease in European influence. We also added new Saramaccan plant name records for rice varieties, of which 41 $(59 \%)$ had European terms in their names. We also found some new European influences in 
plant names recorded earlier by Van Andel et al. (2014). Still, the high proportion of European lexical elements in both studies show that plant naming by enslaved Africans and their descendants in Suriname was strongly influenced by the languages spoken by the English, Dutch and Portuguese plantation owners. For Papiamentu plant names in Curaçao, Alcantara Rodríguez (2016) also found a strong European influence: most lexical items were of Spanish and Portuguese (56\%) or Dutch (25\%) origin, followed by Taino (20\%) (Indigenous) and only 12\% African elements, much less than in the Maroon context. This can be explained by the fact that the Surinamese Maroons lived much more isolated in the rainforest than the people of African descend in Curaçao. Due to their isolation for centuries, the Maroons in Suriname and French Guiana have the highest proportion of African genetic ancestry (98\%) of any African-American population found so far (Fortes-Lima et al. 2017), which clearly had an effect on their plant naming process.

\section{Indigenous influences}

During and after the Saramaccan escaped from the plantations, they were in contact with various indigenous communities from whom they learned plant knowledge, cultural practices and words that can still be seen in Saramaccan plant names. Less than one fifth of the Saramaccan plant names are of indigenous, often Carib and Arawak origin. Some Saramaccan plant names stem from other indigenous languages outside Suriname: the 'kadyu' (Anacardium occidentale L.), comes from the Tupi cajú (Brazil), where it is used for the same species (Alcantara-Rodriguez et al. 2019). This Tupi name (and probably the domesticated cashew as well) came to Suriname via the Sephardic Jews that were thrown out of Dutch Brazil (Van Donselaar 2013). The Saramaccan plant name ‘(a)wassai’ for Varronia schomburgkii (A.DC.) Borhidi is derived from 'yawatai', a Wayapi name given to the botanically related Cordia nodosa Lam. in French Guyana (DeFilipps et al. 2004). The 
Saramaccan name 'kwaytaka nang(r)a' (frog nail) given to Dolichandra unguis-cati (L.) L.G. Lohmann, seems to be an innovation based on 'kwataka', a Wayapi word used for the frog Boana calcarata (Troschel, 1848) (Grenand 1989). The nail (nagra) or hand of the frog resembles the trifid tendrils of the liana that resemble small hooked claws. The influence of indigenous languages that we found in Saramaccan plant names (19\%) was stronger than suggested earlier by Price (2008) who argued that less than $10 \%$ of the Saramaccan came from indigenous languages.

\section{Ethnobotanical source domains}

The Saramaccan plant names contain all sorts of cultural information, and are often fusions of words belonging to various domains. This practice is present among traditional cultures around the world (e.g. Turpin 2013, Fundiko et al. 2015). Since the Saramaccan have an oral culture, plant names help them to classify their natural surroundings, safeguard their cultural knowledge, and remember certain aspects related to the plant's morphology, habitat or use. Huttar (1985), found that different African languages were used for various semantic domains in the Ndyuka language. While the Kwa etymon was prominent in the food domain, Bantu predominated in the domains of flora and fauna and both contributed evenly to the domain related to body parts. The contribution of Kwa and Bantu words could be further investigated for the Saramaccan semantic domains of food and body parts, but its dominance in the natural world was evident in our study as well.

\section{Limitations of this study and future research}

The answer to the question of how and which African languages influenced Saramaccan plant names is a complex one. Some words have survived, while others have not, or have not been documented yet, or were overlooked by us and previous scholars. Those words that did 
survive have often been transformed, making an analysis on their origin interesting but challenging. Sounds do not always correspond with spelling conventions across languages, and spelling rules change over time. Many of the plant names in African languages remain still undocumented, and dictionaries or word lists prepared by missionaries scarcely include terms related to the religious, spiritual and sexual domain. The lack of dictionaries and ethnobotanical research in Central Africa may have created a bias in the language sources and plant names we found so far. We detected relations with Saramaccan plant names and the Congolese Lingala language. Lingala was used as a trade language and was not originally spoken by enslaved Africans in that region (Meeuwis 2019). Many vernacular names in African languages have yet to be linked to reliable botanical specimen data, and more research on Saramaccan plant names is needed to complete our database. Apart from Irvine (1961) for Ghana and Fundiko et al. (2015) for the DRC, etymological studies on African plant names are very scarce. Most ethnobotanical studies and dictionaries do not provide translations for vernacular plant names. Furthermore, a word can enter a language via language contact in a direct manner or indirectly, passed on from one language to another via borrowing. The Saramaccan often borrowed words from Sranantongo into their lexicon (Good, 2009). We are therefore unable to provide a definite answer to the question of the African source of Saramaccan plant names.

Our study showed that ethnobotanical research can add valuable information to the existing linguistic and historal studies on the origin of the enslaved Africans in the New World. Linguists and historicans often document plant names in a way that is not useful to botanists, who need scientific names to contextualize them, while botanists documented plant names with errors as dictionaries where often missing to check them. Vouchering of plant names when doing ethnobotanical research is crucial to be able to link unambiguously local names to scientific names. Therefore, multi-disciplinary research in Africa and the Americas 
is needed, collaborations with universities, and the involvement of native speakers as researchers is highly recommended. Finding evidence for the African legacy of AfroAmerican plant names is far from finished, but so far it has shown the adaptive capacity of humans in a new, challenging environment.

\section{Author statements}

\section{Acknowledgements}

We thank linguist Norval Smith for his valuable insights on the origin of many Saramaccan plant names and sharing his thoughts on the influence of West-African languages in general and Mw. De Boer, native Carib speaker, for providing the meaning of some of Caraib plant names. This study is part of a $\mathrm{PhD}$ project on Saramaccan traditional knowledge for Leiden University Medical Centre (LUMC) in collaboration with Naturalis Leiden.

\section{Competing interest statement}

The authors declare there are no competing interests.

\section{Contributers' statement}

CK and TVA conceptualized the study. PS compiled the MBG database made available for this study. CK compiled the Saramaccan plant database, conducted the analysis, and drafted the manuscript. All authors (except PS) gave input and feedback on the analysis. All authors have read and approved the final manuscript.

\section{Funding statement}

The authors declare no specific funding for this work. 


\section{References}

Aboh, E., and Smith, N. 2015. Migrations, ethnodynamics and geolinguistics in the Eastern Aja-Tado cultural area. In Surviving the Middle Passage: The West Africa-Surinam Sprachbund. Trends in linguistics. Studies and monographs 275. Edited by P. Muysken and N. Smith. De Gruyter Mouton, Berlin. pp. 43-66.

ACT (Amazon Conservation Team). 2015. Biodiversity database Suriname. https://www.ethnobiobase.actsuriname.org/ [Accessed January 13, 2020].

Akoègninou, A., Van der Burg, W.J., and Van der Maesen, L.J.G. 2006. Flore Analytique du Bénin. Backhuys Publishers, Wageningen.

Akuamoa, G.K. 2011. Kwame, the last slave of West Africa. Triangle circlebook, Accra.

Alcantara Rodríguez, M., and Van Andel, T.R. 2019. Plant knowledge in the historia naturalis brasiliae (1648): Retentions of seventeenth-century plant use in Brazil. Econ. Bot. 73(3): 390-404. doi:10.1007/s12231-01909469-w.

Alcantara Rodríguez, M. 2016. African origin of Papiamentu plant names. MSc thesis. Utrecht University, Utrecht. doi:10.13140/RG.2.2.28706.12488.

Arends J. 1999. The origin of the Portuguese element in Surinam Creoles. In Spreading the word. The issue of diffusion among the Atlantic Creoles. Edited by Huber, M., and M. Parkvall. University of West minster Press, London. pp. 195-208.

Arkinstall, W. 1979. Medicinal and useful plants collected in the manianga district of the Republic of Zaïre. Presses de l'Institut de Recherche Scientifique, Kinhasa.

Baumgart, I.R., le Ris Lambers, D., Khodabaks, M.R., and Wildschut, J. 1998. Visit to rice growing sites on the upper Suriname river between Nieuw Aurora and Abenaston. ADRON, Nickerie.

Benjamins, H.D., Snelleman, J.F. 1917. Encyclopaedie van Nederlandsch West-Indië. E.J. Brill, Leiden.

Bentley, W.H. 1895. Dictionary and grammar of the Kongo language, as spoken at San Salvador, the ancient capital of the old Kongo empire, West Africa. Baptist Missionary Society, London. https://archive.org/stream/dictionarygramma00bentuoft/dictionarygramma00bentuoft_djvu.txt [Accessed February 15, 2020]

Berlin, B. 1973. Folk systematics in relation to biological classification and nomenclature. Annual review of Ecology and Systematics 4(1): 259-71. https:///doi.org/10.1146/annurev.es.04.110173.001355 
Berlin, B. 1992. Ethnobiological classification: Principles of categorization of plants and animals in traditional societies. Princeton University Press, Princeton.

Bilby, K. 2000. Reevaluating the African lexical component of the Surinamese Maroon Creoles: The Aluku case. Paper presented at 31st Annual Conference on African Linguistics. Boston University, Boston. https://www.academia.edu/25936551/Reevaluating the_African_Lexical_Component_of_the_Surinamese Maroon_Creoles_The_Aluku_Case?auto=download [Accessed November 5, 2020]

Blench, R. 2007. Hausa names for plant and trees. Cambridge. http://www.rogerblench.info/Ethnoscience/Plants/General/Hausa\%20plant\%20names.pdf [Accessed February 10, 2020]

Blom, A. 1786. Verhandeling over den Landbouw, in de colonie Suriname. Cornelis van der Aa, Haarlem. https://play.google.com/books/reader?id=Sghxutex-TwC\&hl=en\&pg=GBS.PP1 [in Dutch] [Accessed January 21, 2020]

Borges, R. 2015. Amerindian-Maroon interactions in Suriname and the linguistic consequences. In Languages in Contact 2014(5). Edited by P.P. Chruszczewski, Philological School of Higher Education, Wroclav. pp. 99-116. https://www.wsf.edu.pl/upload_module/wysiwyg/Wydawnictwo\%20WSF/LiC5.pdf [Accessed January 5, 2020]

Bruyn, A. 2002. The structure of the Surinamese creoles. In Atlas of the Languages of_Suriname. Edited by E.B. Carlin EB and J. Arends. KITLV Press, Leiden. pp 153-182.

Bum, E.N., Naami, Y.F.C., Soudi, S., Rakotonirina, S.V., and Rakotonrina, S. 2005. Psorospermum febrifugum Spach (Hypericaceae). Decoction antagonized chemically-induced convulsions in mice. International Journal of Pharmacology 1(2): 118-121. doi:10.3923/ijp.2005.118.121.

Burkill, H.M. 1985-2010. Useful plants of West Tropical Africa I-VI. Royal Botanic Gardens, Kew.

CABI, 2020. Sphagneticola trilobata. In Invasive Species Compendium. CAB International, Wallingford. www.cabi.org/isc

Church Missionary Society, 1913. A dictionary of Yoruba language. Church Missionary Society Bookshop, Lagos. http://edeyoruba.com/uploads/3/0/0/1/3001787/yoruba_dictionary.pdf [Accessed March 10, 2020]

Courtz, H. 2008. A Carib grammar and dictionary. Magoria Books, Toronto.

Daeleman, J. 1972. Kongo element in Saramacca tongo. Journal of African Languages 11(1):11-44.

De Souza, S. 2008. Flore du Benin: Nom des plantes dans les langues nationales Beninoises. Tunde, Cotonou. [in French] 
DeFilipps, R.A., Maina, S.L., and Crepin, J. 2004. Medicinal plants of the Guianas (Guyana, Surinam, French Guiana). Smithsonian Institution, Washington DC.

Dingemanse, M. 2018. Redrawing the margins of language: Lessons from research on ideophones. Glossa: A Journal of General Linguistics 3(1): n. pag. doi:http://doi.org/10.5334/gigl.444

Divuilu, F. 2005. English- Lingala, Lingala- English dictionary. First edition, revised. CVO-Books, Congolese Voluntary Organisation, Croydon. https://www.scribd.com/document/370564422/Lingala-Dictionary [Accessed March 10, 2020]

Eberhard, D.M. Simons, G.F., and Fennig, C.D. 2020. Ethnologue: Languages of the World. Twenty-third edition. SIL International, Texas. Online version https://www.ethnologue.com/ [Accessed February 10, 2020].

Edelson, A. 2014. Sailing Against the Current. AuthorHouse, Bloomington.

Eltis, D., and Richardson, D. 2010. Atlas of the transatlantic slave trade. Yale University Press, New Haven. Encyclopaedia Britannica, 2021. Boma. https://www.britannica.com/place/Congo-River [Accessed February 9 , 2021]

Erharuyi, O., Falodun, A., and Langer, P. 2014. Medicinal uses, phytochemistry and pharmacology of Picralima nitida (Apocynaceae) in tropical diseases: A review. Asian Pac. J. Trop. Med 7(1): 1-8. doi:10.1016/S19957645(13)60182-0.

Evangelische Missionsgesellschaft (Evang. Missionary Society). 1909. English-Tshi (Asante): a dictionary. University of California Libraries, Basel. www.archive.org. [Accessed March 5, 2020]

Eweka, A.O., and Enogieru, A. 2011. Effects of oral administration of Phyllanthus amarus leaf extract on the kidneys of adult wistar rats - a histological study. Afr J Tradit Complement Altern Med. 8(3):307-311.

Fanshawe, D.B. 1949. Glossary of Arawak names in Natural History, British Guiana. Int. J. of American Linguistics 15(1): 57-74. https://www.journals.uchicago.edu/doi/pdf/10.1086/464023 [Accessed February $25,2020]$

Fern, K. 2020. Useful Tropical Plants database. http://tropical.theferns.info/ [Accessed August 5, 2020]. Fortes-Lima, C., Gessain, A., Ruiz-Linares, A., Bortolini, M-C., Migot-Nabias, F., Bellis, G., Moreno-Mayar, J.V., Restrepo, B.N., Rojas, W., Avendaño-Tamayo, E., Bedoya, G., Orlando, L., Salas, A., Helgason, A., Thomas, M., Gilbert, P., Sikora, M., Schroeder, H., Dugoujon, J-M. 2017. Genome-wide ancestry and demographic history of African-descendant Maroon communities from French Guiana and Suriname. The American Journal of Human Genetics 101(5): 725-736. https://doi.org/10.1016/j.ajhg.2017.09.021. 
Fundiko, M.C.C., Van Andel, T.R., and Sosef, M.S.M. 2015. Vernacular plant names from the Democratic Republic of the Congo. Trends in folk taxonomy of the Kikongo Kintandu Kiswahili Lingala and Mashi languages. MSc thesis. Leiden University, Leiden. https://www.researchgate.net/publication/321425962

Geetha, K., Ramarao, N., Kiran, R.S., Srilatha, K., Mamatha, P., and Rao, V.U. 2013. An overview on Arachis hypogaea plant. Int. Journal of Pharmaceutical Sciences and Research 4(12): 4508-4518. http://dx.doi.org/10.13040/IJPSR.0975-8232.4(12).4508-18.

Gilman, E.F. 2014. Eugenia uniflora Surinam Cherry. FPS-202. Environmental Horticulture Department, UF/IFAS Extension. 2014. https://edis.ifas.ufl.edu/pdffiles/FP/FP20200.pdf [Accessed February, 2020].

Good, F. 2009. Loanwords in Saramaccan, an English-based Creole of Suriname. In Loanwords in the World's Languages. Edited by Haspelmath, M. and U. Tadmor. De Gruyter Mouton, Berlin. pp. 918-943. doi: https://doi.org/10.1515/9783110218442.918

Grenand, F. 1989. Dictionnaire Wayapi (Guyane Francaise). Peeters Publishers, Paris. [in French]

Hammarström, H., Forkel, R., Haspelmath, M. and Bank, S. 2020. Glottolog 4.3. Jena: Max Planck Institute for the Science of Human History. https://doi.org/10.5281/zenodo.4061162. http://glottolog.org [Accessed August 30, 2020].

Harper, D. 2020. Online Etymology Dictionary. www.etymonline.com. [Accessed March 30, 2020]

Herskovits, M.J., and Herskovits, F.S. 1934. Rebel destiny: among the bush Negroes of Dutch Guiana. McGraw-Hill, New York. https://www.forgottenbooks.com/en/readbook/RebelDestiny 10192482\#0 [Accessed February 5, 2020]

Herskovits, M.J, and Herskovits F.S. 1936. Surinam Folk-Lore. Columbia University Press, New York. https://www.dbnl.org/tekst/hers005suri01_01/index.php [Accessed February 5, 2020]

Huttar, G.L. 1985. Sources of Ndyuka African vocabulary. Nieuwe West Indische Gids 59(1-2): 45-71. Irvine, F. R. 1961. Woody Plants of Ghana. Oxford University Press, Oxford.

Isichei, E. 1997. A history of African Societies to 1870. Cambridge University Press, Cambridge. Jide, F.F. 2010. Extraction and characterisation of Dioclea reflexa Hook. F. Seed Oil. Biological SciencesPJSIR 53(2): 72-75. https://v2.pjsir.org/index.php/biological-sciences/article/view/427 JSTOR Global Plant database, 2020. https://plants.jstor.org/ [Accessed March 5, 2019] Knappert, J. 1979. The development and origin of Lingala. In Readings in Creole studies. Edited by I.F. Hannock. John Benjamins Publishing Agency, Amsterdam. pp.153-165. 
Latham, P., and Konda ku Mbuta, A. 2017. Useful plants of Kongo Central Province, Democratic Republic of Congo 1-2. The Salvation Army, Forneth. https://www.academia.edu/32228861/Useful_Plants_of_Kongo_Central_Province_Democratic_Republic_of Congo Volume 12017 and https://www.academia.edu/32244132/Useful_Plants_of_Kongo_Central_Province_Democratic_Republic_of _Congo_Volume_2_2017_[Accessed on February 26, 2020]

Lautenschläger, T., Monizi, M., Pedro, M., Mandombe, J.L., Bránquima, M.F., Heinze, C., and Neinhuis, C. 2018. First large-scale ethnobotanical survey in the province of Uíge, northern Angola. J. Ethnobiology and Ethnomedicine 14(51): n. pag. https://doi.org/10.1186/s13002-018-0238-3. [Accessed on February 26, 2020] Leyew, Z. 2011. Wild plant nomenclature and traditional botanical knowledge among three ethnolinguistic groups in Northern Ethiopia. OSSREA, Addis Ababa. https://www.google.co.in/books/edition/Wild_Plant_Nomenclature_and_Traditional/OYeevPbyn04C?hl=en $\& \mathrm{gbpv}=1 \& p g=\mathrm{PP} 1 \&$ printsec $=$ frontcover [Accessed March 2020]

Lima, E.F., Medeiros, R.M.T., Cook. D., Lee, S.T., Khaeler, M., Santos-Barbosa, J.M., and Riet-Corrrea, F. 2016. Studies in regard to the classification and putative toxicity of Fridericia japurensis (Arrabidaea japurensis) in Brazil. Toxicon 115: 22-27. https://doi.org/10.1016/j.toxicon.2016.03.001.

Lowes, S., Nunn, N.M., Robinson, J.A., and Weigel, J. 2015. The Evolution of Culture and Institutions: Evidence from the Kuba Kingdom. Working Paper 21798. National bureau of economic research, Cambridge. http://www.nber.org/papers/w21798 [Accessed April 10, 2020]

Makomo, J.C.M. 2012. La politique linguistique de la R.D Congo à l'épreuve du terrain: de l'effort de promotion des langues nationales au surgissement de l'entrelangue. Synerg. Afrique des Gd. Lacs 2: 45-61. https://gerflint.fr/Base/Afrique_GrandsLacs2/makomo. [in French] [Accessed March 10, 2020]

Martin, G.J. 2004. Ethnobotany: a methods manual. Chapman \& Hall, London.

Meeuwis, M. 2019. The linguistic features of Bangala before Lingala: The pidginization of Bobangi in the 1880s and 1890s. Afrikanistik-Aegyptology Online. https://www.afrikanistik-aegyptologieonline.de/archiv/2019/5012/ [Accessed December 15, 2020]

Mintz, S.W., and Price, R. 1992. The birth of African-American culture. An anthropological perspective. Beacon Press, Boston.

Mobley, C.F. 2015. The Kongolese Atlantic: Central African slavery \& culture from Mayombe to Haiti. Duke University, Durham. 
Muturzikiña, 2011. Ethnolinguistic map of the DRC. http://www.muturzikin.com/cartesafrique/12.htm

[Accessed November 5, 2020]

Neuwinger, H.D. 2004. Plants used for poison fishing in tropical Africa. Toxicon 44(4): 417-430.

https://doi.org/10.1016/j.toxicon.2004.05.014.

OED (Oxford English Dictionary). 2020. www.oed.com. [Accessed May 10, 2020]

Pinto, G.P. 1963. Características físcico-químicas e outras informações sobre as principais oleaginosas do Brasil. Instituto de Pesquisas e Experinmentação Agropecuárias do Nordeste. Boletim Técnico 18. [in Portuguese]

Plants for a Future database, 2020. https://pfaf.org/user/Plant.aspx?LatinName=Chrysobalanus + icaco [Accessed May 5, 2020]

Plants of the World Online database, 2020. www.plantsoftheworldonline.org/ [Accessed May 10, 2020]

Price, R. 1973. Maroon Societies: Rebel slave communities in the Americas. Johns Hopkins Univ Press, Baltimore.

Price, R. 1975a. Kikoongo and Saramaccan: A reappraisal. Bijdragen tot de Taal-, Land- en Volkenkunde 131(4): 461-478. Brill, Leiden. https://brill.com/view/journals/bki/131/4/article-p461 3.xml [Accessed March 25, 2020]

Price, R. 1975b. Saramaka social structure: analysis of a maroon society in Suriname (Caribbean monograph series). Institute of Caribbean Studies, University of Puerto Rico, Rio Piedras.

Price, R. 2008. Travels with Tooy: History, Memory, and the African American Imagination. University of Chicago Press, Chicago.

Price, R. 2010. Uneasy neighbors: Maroons and Indians in Suriname. Tipití: Journal of the Society for the Anthropology of Lowland South America 8(2), art.4. n.p.https://digitalcommons.trinity.edu/tipiti/vol8/iss2/4

Price, R. 2013. The maroon population explosion: Suriname and Guyane. New West Indian Guide 87(3-4): 323327. https://doi.org/10.1163/22134360-12340110.

Price, R., and Price, S. 1991. Two evenings in Saramaka. University of Chicago Press, Chicago.

Price, R., and Price, S. 2015. Epilogue: The aesthetics and politics of multilingualism among the Saamaka Chapter. In In and Out of Suriname, Language, Mobility and Identity. Edited by E.B. Carlin, I. Léglise, B. Migge, and P. B. Tjon Sie Fat. Brill, Leiden. pp 253-260. https://www.jstor.org/stable/10.1163/j.ctt1w76x18.16 [Accessed February 5, 2021]

Quattrocchi, U.F.L.S. 2002. CRC World Dictionary of grasses. CRC Press, Boca Raton. 
Quattrocchi, U.F.L.S. 2012. CRC World Dictionary of medicinal and poisonous plants. CRC Press, Boca Raton.

Robinson, C.L. 1914. Hausa- English dictionary. Third edition. Cambridge University Press, Cambridge. https://archive.org/details/dictionaryofhaus02robiuoft/page/n5/mode/2up [Accessed November 5, 2019]

Ruysschaert, S. 2018. Non-timber forest products in Suriname: diversity, knowledge and use in an Amerindian and Maroon community. PhD thesis. Applied Biological Sciences. Ghent University, Ghent. https://lib.ugent.be/catalog/rug01:002490201.

Sauvain, M., Vernon, D., and Fleury, M. 1988. Système de santé moderne et pratiques traditionnelles de santé chez les Noirs Marrons de Guyane et du Surinam. Institut Français de Recherche Scientifique pour le Développement en Coopération ORSTOM, Cayenne. [in French] https://www.documentation.ird.fr/hor/fdi:010010197.

Segurola, B, and Rassinoux, J. 2000. Dictionnaire fon-francais. SMA Société des Missions Africaines, Madrid. [in French]

SIL (Summer Institute of Linguistics), 2003. Languages of Suriname. Sranan-English, Saramaccan-English dictionaries. http://www.suriname-languages.sil.org/ [Accessed March 25, 2019].

Smith, N. 1987. The genesis of the Creole languages of Suriname. PhD thesis. University of Amsterdam, Amsterdam. doi: $10.13140 /$ RG.2.2.10158.20801

Smith, N. 1999. Pernambuco to Suriname 1654-1655? The Jewish slave controversy. In Spreading the word: Papers on the issue of diffusion of Atlantic Creoles. Edited by M. Huber and M. Parkvall. University of Westminister Press, London. pp. 251-298.

Smith, N. 2001. Voodoo Chile: Differential substrate effects in Saramaccan and Haitian. In Creolization and contact. Edited by N. Smith and T. Veenstra. John Benjamins Publishing Company, Amsterdam. pp. 43-80. Smith, N. 2015a. The early history of Suriname. In Surviving the Middle Passage: The West Africa-Surinam Sprachbund. Trends in linguistics. Studies and monographs 275. Edited by P. Muysken and N. Smith. De Gruyter Mouton, Berlin. pp. 17- 42.

Smith, N. 2015b. Substrate phonology, superstrate phonology and adstrate phonology in creole languages. In Surviving the Middle Passage: The West Africa-Surinam Sprachbund. Trends in linguistics. Studies and monographs 275. Edited by P. Muysken and N. Smith. De Gruyter Mouton, Berlin. pp. 261-322.

Smith, N. 2015c. A preliminary list of probable Kikongo lexical items in the Surinam Creole languages. In Surviving the Middle Passage: The West Africa-Surinam Sprachbund. Trends in linguistics. Studies and monographs 275. Edited by P. Muysken and N. Smith. De Gruyter Mouton, Berlin. pp. 417- 462. 
Smith, N. 2015d. A preliminary list of probable Gbe lexical items in the Surinam Creole languages. In Surviving the Middle Passage: The West Africa-Surinam Sprachbund. Trends in linguistics. Studies and monographs 275. Edited by P. Muysken and N. Smith. De Gruyter Mouton, Berlin. pp. 463-467.

Smith, N, and Cardoso, H. 2004. A new look at the Portuguese element in Saramaccan. Journal of Portuguese Linguistics 3(2): 115-147. doi:http://doi.org/10.5334/jpl.14.

Sunmonu, P.O., Oloyede, O.B., Owolarafe, T.A., Yakubu, M.T., and Dosumu, O.O. 2014. Toxicopathological evaluation of Picralima nitida seed aqueous extract in Wistar rats. Türk Biyokimya Dergisi [Turkish Journal of Biochemistry-Turk J Biochem] 39(2): n. pag. doi:10.5505/tjb.2014.83997

Thoden Van Velzen, H.U.E. and W. van Wetering. 1988. The great father and the danger: Religious cults, material forces, and collective fantasies in the world of the Surinamese Maroons. Floris Publications, Dordrecht.

Turpin, M. 2013. Semantic extension in Kaytetye flora and fauna terms. Australian Journal of Linguistics 33 (4): 488-518. doi:10.1080/07268602.2013.857571

Van Andel, T.R., De Korte, S., Koopmans, D., Behari-Ramdas, J., and Ruysschaert, S. 2008. Dry sex in Suriname. J Ethnopharmacol. 116(1): 84-88. https://doi.org/10.1016/j.jep.2007.11.003.

Van Andel, T.R., and Ruysschaert, S. 2011. Medicinale en rituele planten van Suriname. KIT Publishers, Amsterdam.

Van Andel, T.R., Van ’t Klooster, C.I.E.A., Quiroz, D., Towns, A.M., Ruysschaert, S., Van den Berg, M. 2014. Local plant names reveal that enslaved Africans recognized substantial parts of the New World flora. Proc Natl Acad Sci Plus. 111(50): E5346-E5353. https://doi.org/10.1073/PNAS.1418836111.

Van den Berg, M. 2007. A grammar of early Sranan, Manta Zetten. PhD thesis. University of Amsterdam, Amsterdam. http://www.margotvandenberg.info/downloads/vandenBerg AgrammarofEarlySranan 2007.pdf [Accessed January 14, 2020]

Van der Sijs, N. 2010. Etymologiebank. http://etymologiebank.nl/ [Accessed February 25, 2020] [in Dutch] Van Donselaar, J. 1989. Woordenboek van het Surinaams-Nederlands, 2e ed. Coutinho, Muiderberg. [in Dutch]

Van Donselaar, J. 2013. Woordenboek van het Nederlands in Suriname van 1667 tot 1876. Meertens Instituut/Nederlandse Taalunie, Den Haag. [in Dutch]

Vansina, J. 1960. Recording the Oral History of the Bakuba-II. Results. The Journal of African History 1(2): 257-270. http://www.jstor.com/stable/180244 
Vansina, J. 1978. The Children of Woot: A history of the Kuba peoples. University of Wisconsin Press, Madison.

Van Roosmalen, M.G.M. 1985. Fruits of the Guianan flora. Utrecht University/Drukkerij Veenman B.V., Utrecht.

Van 't Klooster C.I.E.A., Lindeman, J.C., and Jansen-Jacobs, M. 2003. Vernacular plant names of Suriname.

Blumea 15. pp. 1-322. Nationaal Herbarium Nederland, Leiden. https://repository.naturalis.nl/pub/603310

Van 't Klooster C., Van Andel, T., Reis, R. 2016. Patterns in medicinal plant knowledge and use in a Maroon village in Suriname. J Ethnopharmacol. 189(2): 319-330. https://doi.org/10.1016/j.jep.2016.05.048.

Van 't Klooster, C.I.E.A., Haabo, V., Ruysschaert, S., Vossen, T., and Van Andel T.R. 2018. Herbal bathing: An analysis of variation in plant use among Saramaccan and Aucan Maroons in Suriname. J. Ethnobiology Ethnomedicine 14(20): n. pag. https://doi.org/10.1186/s13002-018-0216-9.

Van 't Klooster, C.I.E.A., Haabo, V., Van Andel, T.R. 2019. Our children do not have time anymore to learn about medicinal plants: How an ethnobotanical school assignment can contribute to the conservation of Saramaccan Maroon traditional knowledge. Ethnobotany Research \& Applications 18(11): 1-47. http://ethnobotanyjournal.org//index.php/era/article/view/1431.

Vossen, R., and Dimmendaal, G.J. 2020. The Oxford Handbook of African Languages. University Press, Oxford. Digitale bibliotheek voor Nederlandse letteren. www.dbnl.org [Accessed June 5, 2020].

Voyages Database: The Trans-Atlantic Slave Trade Database. 2021. http://www.slavevoyages.org. [Accessed 14 March 2021].

Yaradua, S.S., and Shah, M.M. 2018. Ethnobotanical studies of the genus Crotalaria L. (Crotalarieae, Fabaceae) in Katsina State, Nigeria. Pure Appl. Biol. 7(2): 882-889.

http://dx.doi.org/10.19045/bspab.2018.700107.

\section{Supplementary files}

Supplementary Table S1: Saramaccan Maroon plant names and their (possible) origins (978 records). Plant names constructed from more than one lexical item can have various origins. (References to table are presented at the end of the table together with the used language abbreviations and collectors). 


\section{Table captions}

Table 1: $\quad$ Examples of Saramaccan plant names that strongly resemble African names for botanically related taxa (retentions). 


\begin{tabular}{|c|c|c|c|c|c|c|}
\hline $\begin{array}{l}\text { Sa plant } \\
\text { name } \\
\text { (original) }\end{array}$ & Species Suriname (Family) & $\begin{array}{l}\text { Significance Suriname (Caribbean/South- } \\
\text { America) }\end{array}$ & Significance Africa & $\begin{array}{l}\text { African plant } \\
\text { name (language), } \\
\text { country }\end{array}$ & $\begin{array}{l}\text { African species (family) } \\
\text { (retentions) }\end{array}$ & $\begin{array}{l}\text { Reference } \\
\text { with } \\
\text { species }\end{array}$ \\
\hline $\begin{array}{l}\text { abenbele } \\
\text { (abenbèlè) }\end{array}$ & Pouteria spp. (Sapotaceae) & The red mbele. Pouteria have red fruits. & vè $(\mathrm{Fon})=$ red (Smith 2015d) & mbele (Mba), DRC & $\begin{array}{l}\text { Gambeya africana (A.DC.) } \\
\text { Pierre (Sapotaceae) }\end{array}$ & $\begin{array}{l}\text { MBG } \\
\text { database }\end{array}$ \\
\hline $\begin{array}{l}\text { boniboni } \\
\text { uwii (boni } \\
\text { boni udu) }\end{array}$ & $\begin{array}{l}\text { Maprounea guianensis Aubl. } \\
\text { (Euphorbiaceae) }\end{array}$ & Uwíi (Sa)= weed (En) (Smith 1987) & & $\begin{array}{l}\text { mbunji (Kiyaka), } \\
\text { DRC }\end{array}$ & $\begin{array}{l}\text { Maprounea africana } \\
\text { Müll.Arg. (Euphorbiaceae) }\end{array}$ & $\begin{array}{l}\text { MBG } \\
\text { database }\end{array}$ \\
\hline $\begin{array}{l}\text { kisangula } \\
\text { (kisangula, } \\
\text { kisangoloa) }\end{array}$ & $\begin{array}{l}\text { Maprounea guianensis Aubl. } \\
\text { (Euphorbiaceae) }\end{array}$ & & ngola (Lingala) = red (Divuilu 2005). & $\begin{array}{l}\text { kinsangula } \\
\text { (Kikongo), DRC }\end{array}$ & $\begin{array}{l}\text { Maprounea africana } \\
\text { Müll.Arg. (Euphorbiaceae) }\end{array}$ & $\begin{array}{l}\text { Arkinstall } \\
(1979)\end{array}$ \\
\hline $\begin{array}{l}\text { komatisangu } \\
\text { (komanti } \\
\text { sangu) }\end{array}$ & $\begin{array}{l}\text { Senna occidentalis } \\
\text { (Fabaceae) }\end{array}$ & Kormantse $=$ Ghanaian fort Coromantine. & $\begin{array}{l}\text { Kormantse = village in Ghana where Dutch } \\
\text { slavefort Coromantine was located. The } \\
\text { 'Koromantijners', as the enslaved Africans from } \\
\text { Kromantse were refered to, were known to be } \\
\text { strong and profound in magic and herbal healing } \\
\text { (Van Andel and Ruysschaert 2011) }\end{array}$ & $\begin{array}{l}\text { insangi (Kikongo), } \\
\text { DRC }\end{array}$ & $\begin{array}{l}\text { Senna occidentalis (L.) } \\
\text { Link (Fabaceae) }\end{array}$ & $\begin{array}{l}\text { MBG } \\
\text { database }\end{array}$ \\
\hline $\begin{array}{l}\text { lotauwii } \\
\text { (lotawi) }\end{array}$ & $\begin{array}{l}\text { Erigeron bonariensis } \mathrm{L} \text {. } \\
\text { (Asteraceae) }\end{array}$ & $\begin{array}{l}\text { Lota }(\mathrm{Sa})=\text { skin infection pityriasis versicolor with } \\
\text { flaky discoloured patches. Spots on skin (Smith } \\
2015 \mathrm{c}) . \text { Uwíi (Sa)= weed (En) (Smith 1987). }\end{array}$ & $\begin{array}{l}\text { loota (Yoruba) }=\text { skin disease, squamous skin } \\
\text { disease (Smith 2015c). Solanecio cydoniifolius is } \\
\text { used against sores (Burkill 1985-2010). }\end{array}$ & $\begin{array}{l}\text { mulota (Lega- } \\
\text { Mwenga), DRC }\end{array}$ & $\begin{array}{l}\text { Solanecio cydoniifolius }(\mathrm{O} . \\
\text { Hoffm) C. Jeffrey } \\
\text { (Asteraceae) }\end{array}$ & $\begin{array}{l}\text { MBG } \\
\text { database }\end{array}$ \\
\hline $\begin{array}{l}\text { malembe } \\
\text { toko } \\
\text { (malëmbê } \\
\text { tökö) }\end{array}$ & Piper spp. (Piperaceae) & $\begin{array}{l}\text { Piper spp. are used in herbal bathing to 'calm' down } \\
\text { spirits (Van Andel and Ruysschaert 2011). }\end{array}$ & $\begin{array}{l}\text { toko (Kikongo) = man (Bentley 1895), } \\
\text { malembalemba (Kikongo)= going on well, } \\
\text { comfortably (Bentley 1895). [lembe } \\
\text { (Lingala)=soft, relax (Fundiko et al. 2015)] }\end{array}$ & $\begin{array}{l}\text { lemba ntoko } \\
\text { (Kikongo), DRC }\end{array}$ & $\begin{array}{l}\text { Piper umbellatum } \mathrm{L} . \\
\text { (Piperaceae) }\end{array}$ & $\begin{array}{l}\text { MBG } \\
\text { database }\end{array}$ \\
\hline $\begin{array}{l}\text { manbaai } \\
\text { (manbaaj) }\end{array}$ & $\begin{array}{l}\text { Strychnos cf. medeola Sagot } \\
\text { ex Progel (Loganiaceae) }\end{array}$ & & 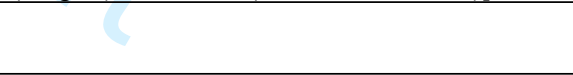 & $\begin{array}{l}\text { magboy (Zande), } \\
\text { DRC }\end{array}$ & $\begin{array}{l}\text { Strychnos spinosa Lam. } \\
\text { (Loganiaceae) }\end{array}$ & $\begin{array}{l}\text { MBG } \\
\text { database }\end{array}$ \\
\hline $\begin{array}{l}\text { mayaya } \\
\text { (majaja) }\end{array}$ & Oryza sativa L. (Poaceae) & $\begin{array}{l}\text { Type of rice (white husks and grain). Mayaya }(\mathrm{Sa})= \\
\text { type of grass. }\end{array}$ & & $\begin{array}{l}\text { ma-dyaadya } \\
\text { (Kikongo), DRC }\end{array}$ & Several species of Poaceae & $\begin{array}{l}\text { Smith } \\
(2015 c)\end{array}$ \\
\hline $\begin{array}{l}\text { mazikazika } \\
\text { (masikásiká, } \\
\text { masigasiga) }\end{array}$ & $\begin{array}{l}\text { Eleusine indica (L.) Gaertn. } \\
\text { (Poaceae) }\end{array}$ & & $\begin{array}{l}\text { ki-zika-zika }(\text { Kikongo) }=\text { a grass }(\text { Daeleman } \\
\text { 1972) }\end{array}$ & $\begin{array}{l}\text { masikasika/zikazika } \\
\text { (Kikongo), DRC }\end{array}$ & $\begin{array}{l}\text { Eleusine indica (L.) Gaertn. } \\
\text { (Poaceae) }\end{array}$ & $\begin{array}{l}\text { MBG } \\
\text { database }\end{array}$ \\
\hline $\begin{array}{l}\text { mutene } \\
\text { (mutene) }\end{array}$ & Eugenia sp. (Myrtaceae) & $\begin{array}{l}\text { Most Eugenia spp. have flaky barks. The Surinamese } \\
\text { species E. uniflora has a peeling bark (Gilman 2014). }\end{array}$ & motende (Lingala) = carving (Divuilu 2005) & $\begin{array}{l}\text { tendende (Luba- } \\
\text { Kasai), DRC }\end{array}$ & $\begin{array}{l}\text { Eugenia malangensis }(\mathrm{O} . \\
\text { Hoffm.) Nied (Myrtaceae) }\end{array}$ & $\begin{array}{l}\begin{array}{l}\text { MBG } \\
\text { database }\end{array} \\
\end{array}$ \\
\hline $\begin{array}{l}\text { tunbalobi } \\
\text { (tunbalobi) }\end{array}$ & Cordia spp. (Boraginaceae) & $\begin{array}{l}\text { Lóbi (Sa) }=\text { love (En) (Smith 1987). Cordia } \\
\text { bahamensis (West Indies) is used as a love potion } \\
\text { (Quattrocchi 2012). }\end{array}$ & $\begin{array}{l}\text { bu-ntumba }(\text { Kikongo })=\text { belle femme, beautiful } \\
\text { woman, ntumba }(\text { Kikongo) = jeune demoiselle } \\
(\text { Smith 2015c). }\end{array}$ & $\begin{array}{l}\text { kitumba (Talinga), } \\
\text { DRC }\end{array}$ & $\begin{array}{l}\text { 1. Cordia africana Lam. } \\
\text { (Boraginaceae) }\end{array}$ & $\begin{array}{l}\text { Quattrocchi } \\
\text { (2012) }\end{array}$ \\
\hline $\begin{array}{l}\text { wandyaa } \\
\text { (waja, wanja, } \\
\text { wandja) }\end{array}$ & $\begin{array}{l}\text { Sesamum indicum } \mathrm{L} . \\
\text { (Pedaliaceae) }\end{array}$ & $\begin{array}{l}\text { According to Marcgrave and Piso }(1648,1658) \\
\text { sesame (Sesamum indicum) was refered to as } \\
\text { 'gangila' by the Congo people and got introduced } \\
\text { from Africa to Brazil by the Portuguese colonizers } \\
\text { (Alcantara Rodríguez and Van Andel } 2019) \text {. } \\
\text { Introduced to Suriname via the Portuguese Jews or } \\
\text { during African slave trade from Africa to Suriname. }\end{array}$ & & $\begin{array}{l}\text { 1. wangila wu } \\
\text { Matebo (Kikongo), } \\
\text { 2. wangila } \\
\text { (Kikongo), DRC }\end{array}$ & $\begin{array}{l}\text { Sesamum indicum L. } \\
\text { (Pedaliaceae) }\end{array}$ & $\begin{array}{l}\text { 1. MBG } \\
\text { database, } 2 . \\
\text { Latham } \\
\text { and Konda } \\
\text { ku Mbuta } \\
(2017)\end{array}$ \\
\hline $\begin{array}{l}\text { wangi(wangi, } \\
\text { wandji) }\end{array}$ & $\begin{array}{l}\text { Bagassa guianensis Aubl. } \\
\text { (Moraceae) }\end{array}$ & $\begin{array}{l}\text { Lukwandyi, lukwangi (Sa, 1778) = twigs of fallen } \\
\text { tree, branch without leaves; bushes (Smith 2015c). }\end{array}$ & $\begin{array}{l}\text { vwángi (Kikongo) = thicket, brushwood (Smith } \\
\text { 2015c) }\end{array}$ & $\begin{array}{l}\text { mbangi (Zande), } \\
\text { DRC }\end{array}$ & $\begin{array}{l}\text { Milicia excelsa (Welw.) } \\
\text { C.C. Berg (Moraceae) }\end{array}$ & $\begin{array}{l}\text { MBG } \\
\text { database }\end{array}$ \\
\hline
\end{tabular}




\section{Figure captions}

Figure 1: $\quad$ Left: Saramaccan Maroon village Pikin See. Yeeye Haabo ${ }^{\dagger}$, Pikin Slee. Photographs made by C. van 't Klooster (2009). Right: Map of Suriname and the Maroon communities living in the interior. Drawing by Hendrik Rypkema, Naturalis Biodiversity Center, is reproduced by permission of Naturalis Biodiversity Center.

Figure 2: $\quad$ Language families and subfamilies (presented in subfigures A-F) belonging to the Niger Congo phylum contributing to Saramaccan retentions in $\%$. 

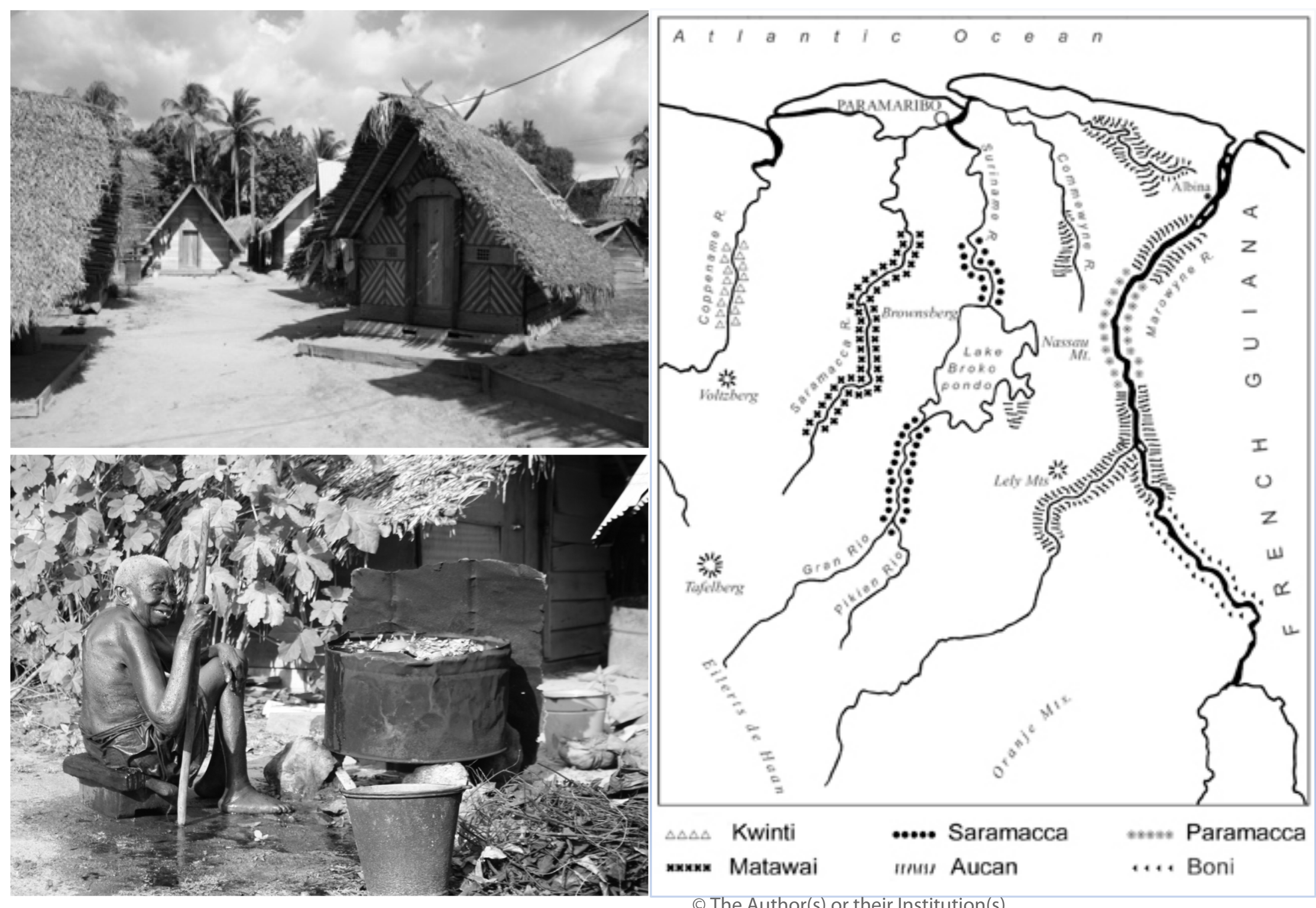

O The Author(s) or their Institution(s) 


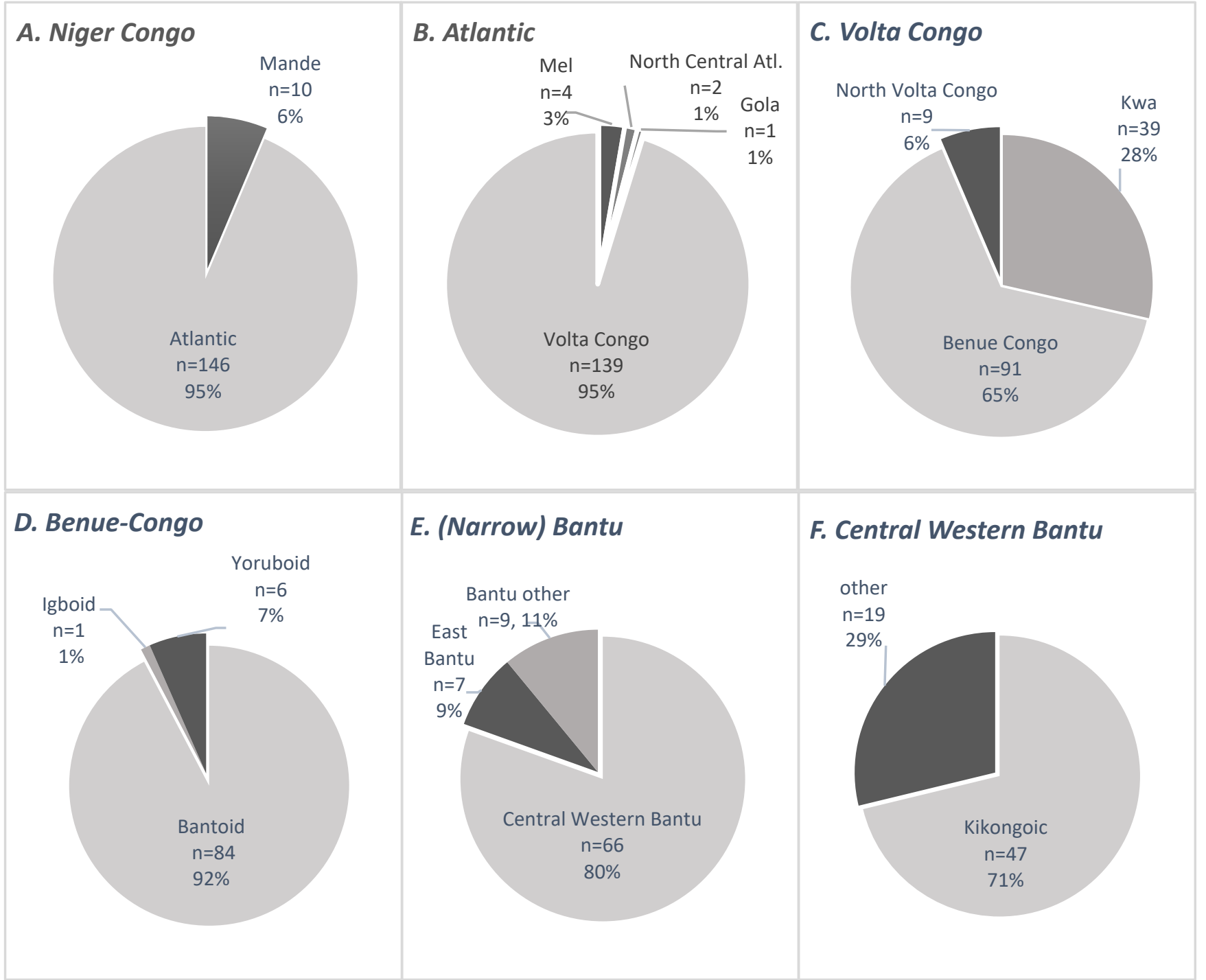

(c) The Author(s) or their Institution(s) 
Table 1: Examples of Saramaccan (Sa) plant names that strongly resemble African names for botanically related taxa (retentions).

\begin{tabular}{|c|c|c|c|c|c|c|}
\hline $\begin{array}{l}\text { Sa plant } \\
\text { name } \\
\text { (original) }\end{array}$ & $\begin{array}{l}\text { Species Suriname } \\
\text { (Family) }\end{array}$ & Significance Suriname (Caribbean/South-America) & Significance Africa & $\begin{array}{l}\text { African plant name } \\
\text { (language), country }\end{array}$ & $\begin{array}{l}\text { African species (family) } \\
\text { (retentions) }\end{array}$ & $\begin{array}{l}\text { Referenc } \\
\text { e with } \\
\text { species } \\
\end{array}$ \\
\hline $\begin{array}{l}\text { abenbele } \\
\text { (abenbèlè) }\end{array}$ & $\begin{array}{l}\text { Pouteria spp. } \\
\text { (Sapotaceae) }\end{array}$ & The red mbele. Pouteria have red fruits. & vè $(F o n)=$ red $($ Smith 2015d) & mbele (Mba), DRC & $\begin{array}{l}\text { Gambeya africana (A.DC.) } \\
\text { Pierre (Sapotaceae) }\end{array}$ & $\begin{array}{l}\text { MBG } \\
\text { database }\end{array}$ \\
\hline $\begin{array}{l}\text { boniboni } \\
\text { uwii (boni } \\
\text { boni udu) }\end{array}$ & $\begin{array}{l}\text { Maprounea guianensis } \\
\text { Aubl. (Euphorbiaceae) }\end{array}$ & Uwíi (Sa)= weed (En) (Smith 1987) & & $\begin{array}{l}\text { mbunji (Kiyaka), } \\
\text { DRC }\end{array}$ & $\begin{array}{l}\text { Maprounea africana } \\
\text { Müll.Arg. (Euphorbiaceae) }\end{array}$ & $\begin{array}{l}\text { MBG } \\
\text { database }\end{array}$ \\
\hline $\begin{array}{l}\text { kisangula } \\
\text { (kisangula, } \\
\text { kisangoloa) }\end{array}$ & $\begin{array}{l}\text { Maprounea guianensis } \\
\text { Aubl. (Euphorbiaceae) }\end{array}$ & & ngola $($ Lingala $)=$ red (Divuilu 2005) & $\begin{array}{l}\text { kinsangula (Kikongo), } \\
\text { DRC }\end{array}$ & $\begin{array}{l}\text { Maprounea africana } \\
\text { Müll.Arg. (Euphorbiaceae) }\end{array}$ & $\begin{array}{l}\text { Arkinstall } \\
\text { (1979) }\end{array}$ \\
\hline $\begin{array}{l}\text { komatisangu } \\
\text { (komanti } \\
\text { sangu) }\end{array}$ & $\begin{array}{l}\text { Senna occidentalis } \\
\text { (Fabaceae) }\end{array}$ & Kormantse $=$ Ghanaian fort Coromantine. & $\begin{array}{l}\text { Kormantse = village in Ghana where Dutch slavefort } \\
\text { Coromantine was located. The 'Koromantijners', as the } \\
\text { enslaved Africans from Kromantse were refered to, were } \\
\text { known to be strong and profound in magic and herbal } \\
\text { healino (Van Andeland Ruvsschaert } 2011 \text { ) }\end{array}$ & $\begin{array}{l}\text { insangi (Kikongo), } \\
\text { DRC }\end{array}$ & $\begin{array}{l}\text { Senna occidentalis (L.) Link } \\
\text { (Fabaceae) }\end{array}$ & $\begin{array}{l}\text { MBG } \\
\text { database }\end{array}$ \\
\hline $\begin{array}{l}\text { lotauwii } \\
\text { (lotawi) }\end{array}$ & $\begin{array}{l}\text { Erigeron bonariensis } \\
\text { L. (Asteraceae) }\end{array}$ & $\begin{array}{l}\text { Lota }(\mathrm{Sa})=\text { skin infection pityriasis versicolor with flaky } \\
\text { discoloured patches, vitiligo. Infection with spots on skin } \\
\text { (Smith 2015c). Uwii (Sa)= weed (En) (Smith 1987). }\end{array}$ & $\begin{array}{l}\text { loota (Yoruba) =skin disease, squamous skin disease } \\
\text { (Smith 2015c). Solanecio cydoniifolius is used against } \\
\text { sores (Burkill 1985-2010). }\end{array}$ & $\begin{array}{l}\text { mulota (Lega- } \\
\text { Mwenga), DRC }\end{array}$ & $\begin{array}{l}\text { Solanecio cydoniifolius (O. } \\
\text { Hoffm) C. Jeffrey } \\
\text { (Asteraceae) }\end{array}$ & $\begin{array}{l}\text { MBG } \\
\text { database }\end{array}$ \\
\hline $\begin{array}{l}\text { malembe } \\
\text { toko } \\
\text { (malëmbê }\end{array}$ & $\begin{array}{l}\text { Piper spp. } \\
\text { (Piperaceae) }\end{array}$ & $\begin{array}{l}\text { Piper spp. are used in herbal bathing to 'calm' down spirits } \\
\text { (Van Andel and Ruysschaert 2011). }\end{array}$ & $\begin{array}{l}\text { toko (Kikongo) }=\text { man (Bentley 1895), malembalemba } \\
\text { (Kikongo)= going on well, comfortably (Bentley } \\
\text { 1895). [lembe (Lingala)=soft, relax (Fundiko et al. 2015)] }\end{array}$ & $\begin{array}{l}\text { lemba ntoko } \\
\text { (Kikongo), DRC }\end{array}$ & $\begin{array}{l}\text { Piper umbellatum } \mathrm{L} . \\
\text { (Piperaceae) }\end{array}$ & $\begin{array}{l}\text { MBG } \\
\text { database }\end{array}$ \\
\hline $\begin{array}{l}\text { manbaai } \\
\text { (manbaaj) }\end{array}$ & $\begin{array}{l}\text { Strychnos cf. medeola } \\
\text { Sagot ex Progel }\end{array}$ & & & $\begin{array}{l}\text { magboy (Zande), } \\
\text { DRC }\end{array}$ & $\begin{array}{l}\text { Strychnos spinosa Lam. } \\
\text { (Loganiaceae) }\end{array}$ & $\begin{array}{l}\text { MBG } \\
\text { database }\end{array}$ \\
\hline $\begin{array}{l}\text { mayaya } \\
\text { (maiaia) }\end{array}$ & $\begin{array}{l}\text { Oryza sativa } \mathrm{L} \text {. } \\
\text { (Poaceae) }\end{array}$ & $\begin{array}{l}\text { Type of rice (white husks and grain). Mayaya }(\mathrm{Sa})=\text { type of } \\
\text { grass. }\end{array}$ & & $\begin{array}{l}\text { ma-dyaadya } \\
\text { (Kikonoo..DRC }\end{array}$ & Several species of Poaceae & $\begin{array}{l}\text { Smith } \\
(2015 \mathrm{c})\end{array}$ \\
\hline $\begin{array}{l}\text { mazikazika } \\
\text { (masikásiká, } \\
\text { masigasiga) }\end{array}$ & $\begin{array}{l}\text { Eleusine indica (L.) } \\
\text { Gaertn. (Poaceae) }\end{array}$ & & ki-zika-zika $($ Kikongo $)=$ a grass $($ Daeleman 1972$)$ & $\begin{array}{l}\text { masikasika/zikazika } \\
\text { (Kikongo), DRC }\end{array}$ & $\begin{array}{l}\text { Eleusine indica }(\mathrm{L} .) \text { Gaertn. } \\
\text { (Poaceae) }\end{array}$ & $\begin{array}{l}\text { MBG } \\
\text { database }\end{array}$ \\
\hline $\begin{array}{l}\text { mutene } \\
\text { (mutene) }\end{array}$ & $\begin{array}{l}\text { Eugenia sp. } \\
\text { (Myrtaceae) }\end{array}$ & $\begin{array}{l}\text { Most Eugenia spp. have flaky barks. The Surinamese species } \\
\text { E. uniflora has a peeling bark (Gilman 2014). }\end{array}$ & motende $($ Lingala $)=$ carving (Divuilu 2005) & $\begin{array}{l}\text { tendende (Luba- } \\
\text { Kasai), DRC }\end{array}$ & $\begin{array}{l}\text { Eugenia malangensis (O. } \\
\text { Hoffm.) Nied (Myrtaceae) }\end{array}$ & $\begin{array}{l}\text { MBG } \\
\text { database }\end{array}$ \\
\hline $\begin{array}{l}\text { tunbalobi } \\
\text { (tunbalobi) } \\
\end{array}$ & $\begin{array}{l}\text { Cordia spp. } \\
\text { (Boraginaceae) }\end{array}$ & $\begin{array}{l}\text { Lóbi (Sa) = love (En) (Smith 1987). Cordia bahamensis (West } \\
\text { Indies) is used as a love potion (Quattrocchi 2012). }\end{array}$ & $\begin{array}{l}\text { bu-ntumba (Kikongo) = belle femme, beautiful woman, } \\
\text { ntumba (Kikongo) = ieune demoiselle (Smith 2015c). }\end{array}$ & $\begin{array}{l}\text { kitumba (Talinga), } \\
\text { DRC }\end{array}$ & $\begin{array}{l}\text { 1. Cordia africana Lam. } \\
\text { (Boraginaceae) }\end{array}$ & $\begin{array}{l}\text { Quattrocc } \\
\text { hi (2012) } \\
\end{array}$ \\
\hline $\begin{array}{l}\text { wandyaa } \\
\text { (waja, } \\
\text { wanja, } \\
\text { wandja) }\end{array}$ & $\begin{array}{l}\text { Sesamum indicum } \mathrm{L} \text {. } \\
\text { (Pedaliaceae) }\end{array}$ & $\begin{array}{l}\text { According to Marcgrave and Piso }(1648,1658) \text { sesame } \\
\text { (Sesamum indicum) was refered to as 'gangila' by the Congo } \\
\text { people and got introduced from Africa to Brazil by the } \\
\text { Portuguese colonizers (Alcantara Rodríguez and Van Andel } \\
\text { 2019). Introduced to Suriname via the Portuguese Jews or } \\
\text { during the African slave trade from Africa to Suriname. }\end{array}$ & & $\begin{array}{l}\text { 1. wangila wu Matebo } \\
\text { (Kikongo), 2. wangila } \\
\text { (Kikongo), DRC }\end{array}$ & $\begin{array}{l}\text { Sesamum indicum } \mathrm{L} . \\
\text { (Pedaliaceae) }\end{array}$ & $\begin{array}{l}\text { 1. MBG } \\
\text { database, } \\
\text { 2. Latham } \\
\text { and } \\
\text { Konda ku } \\
\text { Mbuta }\end{array}$ \\
\hline $\begin{array}{l}\text { wangi(wangi } \\
\text { wandii) }\end{array}$ & $\begin{array}{l}\text { Bagassa guianensis } \\
\text { Aubl.(Moraceae) }\end{array}$ & $\begin{array}{l}\text { Lukwandyi, lukwangi }(\mathrm{Sa}, 1778)=\text { twigs of fallen tree, branch } \\
\text { without leaves: bushes (Smith 2015c). }\end{array}$ & $\begin{array}{l}\text { vwángi (Kikongo) = thicket, brushwood (Smith 2015c) } \\
\text { and evwangi (Kikongo) iungle of brushwood. }\end{array}$ & DRC & $\begin{array}{l}\text { Milicia excelsa }(\text { Welw.) } \\
\text { C.C. Berg (Moraceae) }\end{array}$ & $\begin{array}{l}\text { MBG } \\
\text { database }\end{array}$ \\
\hline
\end{tabular}

